\title{
Aquaculture-related stress on rainbow trout (Oncorhynchus mykiss) and Arctic char (Salvelinus alpinus)
}

Christopher D. Nelson

West Virginia University

Follow this and additional works at: https://researchrepository.wvu.edu/etd

\section{Recommended Citation}

Nelson, Christopher D., "Aquaculture-related stress on rainbow trout (Oncorhynchus mykiss) and Arctic char (Salvelinus alpinus)" (2003). Graduate Theses, Dissertations, and Problem Reports. 1799. https://researchrepository.wvu.edu/etd/1799

This Thesis is protected by copyright and/or related rights. It has been brought to you by the The Research Repository @ WVU with permission from the rights-holder(s). You are free to use this Thesis in any way that is permitted by the copyright and related rights legislation that applies to your use. For other uses you must obtain permission from the rights-holder(s) directly, unless additional rights are indicated by a Creative Commons license in the record and/ or on the work itself. This Thesis has been accepted for inclusion in WVU Graduate Theses, Dissertations, and Problem Reports collection by an authorized administrator of The Research Repository @ WVU. For more information, please contact researchrepository@mail.wvu.edu. 
Aquaculture-related Stress on Rainbow Trout (Oncorhynchus mykiss) and Arctic Char (Salvelinus alpinus)

\author{
Christopher D. Nelson
}

\begin{abstract}
Thesis submitted to
The Davis College of Agriculture, Forestry, and Consumer Sciences at West Virginia University

In partial fulfillment of the requirements for the degree of

Master of Science

in

Wildlife and Fisheries Resources
\end{abstract}

Approved by

Dr. Patricia Mazik, Ph. D., Chair

Dr. Stuart Welsh, Ph. D.

Dr. P. Brett Kenney, Ph. D.

Division of Forestry

\title{
Morgantown, West Virginia 2003
}

Keywords: aquaculture, rainbow trout, Arctic char, nitrite, carbon dioxide, transport, anesthetics, fish, stress

Copyright 2003 Christopher D. Nelson 


\section{Abstract \\ Aquaculture-related Stress on Rainbow Trout (Oncorhynchus mykiss) and Arctic Char (Salvelinus alpinus)}

\section{Christopher D. Nelson}

Recent expansions in aquaculture characterize it as one of the fastest growing segments of the U.S. agricultural sector. Expansion has been facilitated by increased production of many important aquatic species including catfish, salmon, trout, tilapia, shrimp, oysters, and crawfish. West Virginia aquaculture, also an expanding industry, is currently characterized by small-scale, widely dispersed farms. To facilitate future expansion of aquaculture in West Virginia, focuses on product quality as well as production efficiency, identification of limiting factors and investigation into new or alternative management techniques are needed. Objectives of this project were to determine the effects of nitrite and carbon dioxide on the survival and physiological responses of rainbow trout and to evaluate the effectiveness of fish transport with anesthesia on reducing the physiological responses of Arctic char. Results from this project indicate that nitrite toxicity is affected by elevations in environmental carbon dioxide, and conversely, carbon dioxide tolerance is affected by environmental nitrite concentrations. Results

also indicate that the anesthetic treatments investigated in this project (AQUI-S ${ }^{\mathrm{TM}}$, ice-slurry, and carbon dioxide) were not effective in consistently reducing the physiological responses of Arctic char during a simulated transport. We feel that additional experiments examining the interacting effects of nitrite and carbon dioxide on fish are needed to identify the physiological mechanisms or effects that lead to increased nitrite and carbon dioxide toxicities in fish, and additional experiments evaluating efficient procedures of reducing physiological responses of fish during transport is also needed. 


\section{Acknowledgements}

The author wishes to thank his committee members Drs. Patricia Mazik, Stuart Welsh, and Brett Kenney for their support, and guidance in the completion of this project. The author also would like to thank Melody Danley for her tremendous assistance in all aspects of completing this project. Additionally, the author would like to acknowledge and thank Dr. George Seidel for his statistical assistance during the completion of this project. Finally, the author would like to acknowledge that this study was conducted as part of the Aquaculture Food and Marketing Development Project (Aqua 3) at West Virginia University and was funded by the USDA Cooperative State Research, Education and Extension Service. Additional support was provided by the West Virginia Cooperative Fish and Wildlife Research Unit (USGS, BRD) and the Division of Forestry at West Virginia University. Special thanks go to the Conservation Fund's Freshwater Institute for providing excellent facilities, help, and support. 


\section{Foreword}

This thesis has been formatted for submission to the North American Journal of Aquaculture, according to the journal's manuscript preparation guidelines published 


\section{Table of Contents}

\section{CHAPTER 1: EFFECTS OF NITRITE AND CARBON DIOXIDE IN RAINBOW TROUT}

(ONCORHYNCHUS MYKISS): SURVIVAL AND PHYSIOLOGICAL RESPONSES .......................................1

ABSTRACT … -

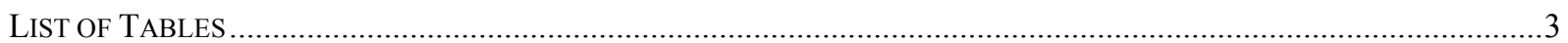

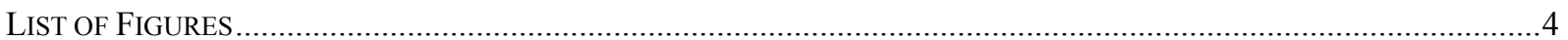

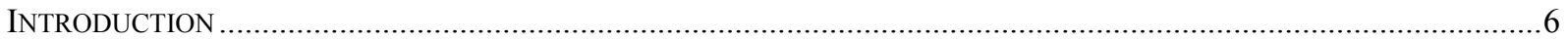

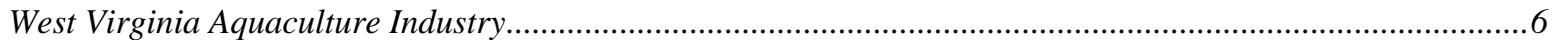

Carbon Dioxide Challenges in the WV Aquaculture Industry .........................................................................

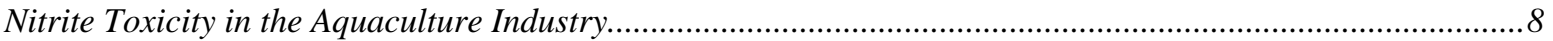

Nitrite and $\mathrm{CO}_{2}$ challenges in the West Virginia Aquaculture Industry .......................................................10

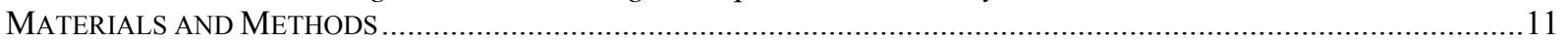

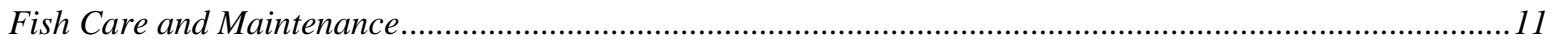

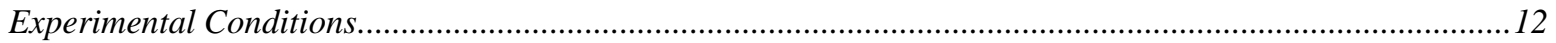

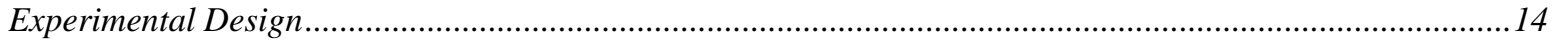

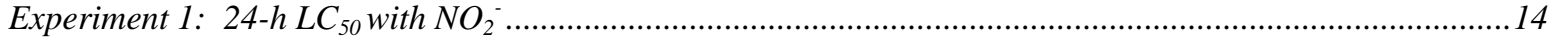

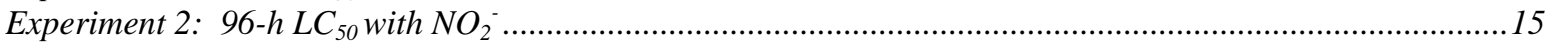

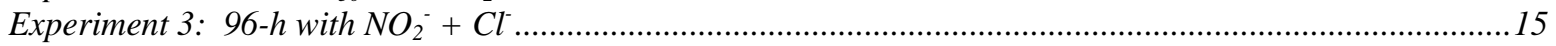

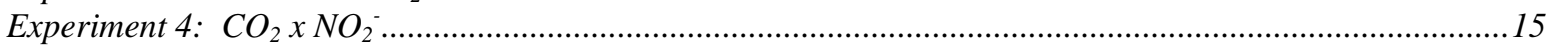

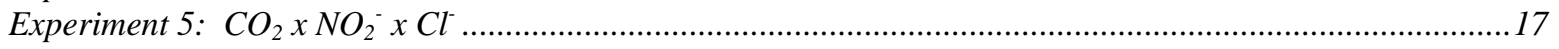

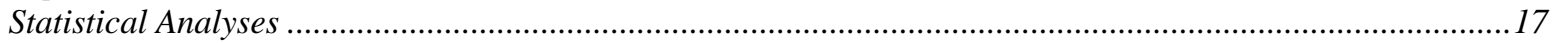

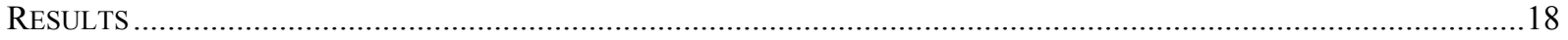

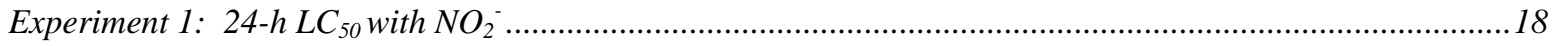

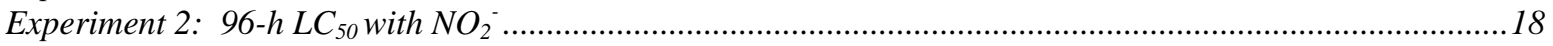

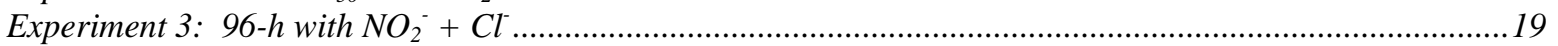

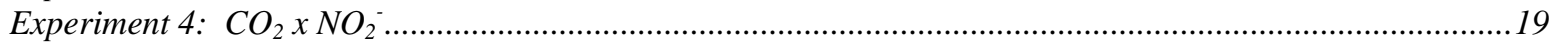

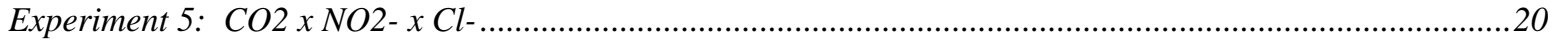

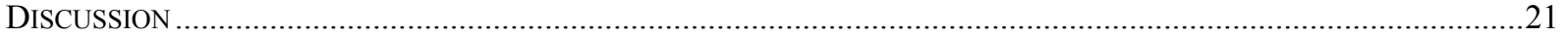

Nitrite Toxicity During Normocapnia ...........................................................................................................21

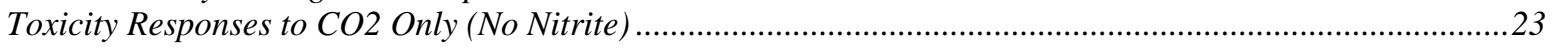

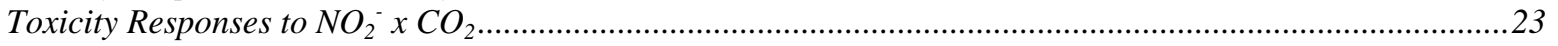

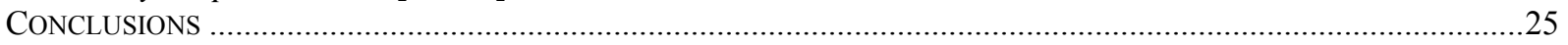

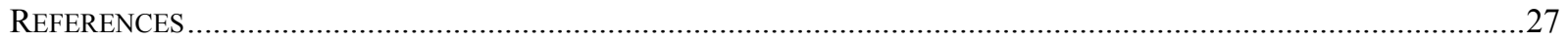

Tables

Table 1. Blood and plasma parameters of rainbow trout from experiment 1 ....................................................33

Table 2. Blood and plasma parameters of rainbow trout from experiment 2 ..................................................34

Table 3. Blood and plasma parameters of rainbow trout from experiment 3 .....................................................35

Table 4. Blood and plasma parameters of rainbow trout from experiment 4 .................................................36

Table 5. Blood and plasma parameters of rainbow trout from experiment 5 ....................................................3

Figures

Figure 1. Percent mortality of rainbow trout exposed for $24 \mathrm{~h}$ to environmental nitrite-N............................38

Figure 2. Plasma nitrite in rainbow trout exposed for $24 \mathrm{~h}$ to increasing concentrations of environmental

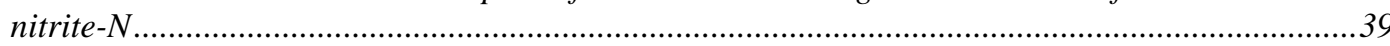

Figure 3. Plasma chloride in rainbow trout exposed for $24 \mathrm{~h}$ to increasing concentrations of environmental

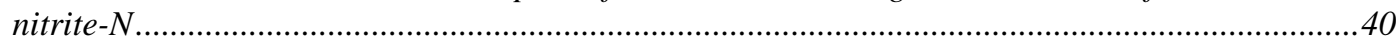

Figure 4. Percent mortality of rainbow trout exposed for $96 \mathrm{~h}$ to environmental nitrite-N............................41

Figure 5. Plasma nitrite in rainbow trout exposed for $96 \mathrm{~h}$ to increasing concentrations of environmental nitrite- $N$.

Figure 6. Percent survival of rainbow trout exposed for $96 \mathrm{~h}$ to a lethal level of nitrite- $N$ to increasing concentrations of environmental chloride.

Figure 7. Plasma nitrite in rainbow trout exposed for $96 \mathrm{~h}$ to a lethal level of nitrite- $N$ in increasing

Figure 8. Plasma lactate in rainbow trout exposed for $96 \mathrm{~h}$ to a lethal level of nitrite- $N$ in increasing 
concentrations of environmental chloride.

Figure 9. Percent mortality of rainbow trout exposed for $96 \mathrm{~h}$ to increasing concentrations of environmental nitrite- $N$ and carbon dioxide

Figure 10. Percent survival of rainbow trout exposed for $96 \mathrm{~h}$ to a lethal level of nitrite- $N$ to increasing concentrations of environmental chloride and carbon dioxide.

Figure 11. Plasma nitrite in rainbow trout exposed for $96 \mathrm{~h}$ to a lethal of nitrite- $N$ in increasing concentrations of environmental chloride and carbon dioxide... 48

Figure 12. Plasma chloride in rainbow trout exposed for $96 \mathrm{~h}$ to a lethal of nitrite- $N$ in increasing concentrations of environmental chloride and carbon dioxide.

Appendices

Appendix A. Water quality values (mean \pm SEM) from experiments one through five. 50

Appendix B. Formulas for calculating the amounts of sodium nitrite and sodium chloride to add to reach target concentrations in the water.

CHAPTER 2: PHYSIOLOGICAL RESPONSES OF ARCTIC CHAR (SALVELINUS ALPINUS) DURING A 5.5 HOUR TRANSPORT WITH ICE-SLURRY, AQUI-S ${ }^{\text {TM }}$, AND CARBON DIOXIDE...........................52

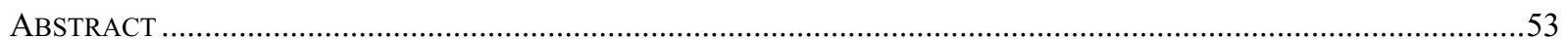

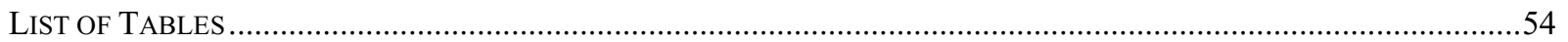

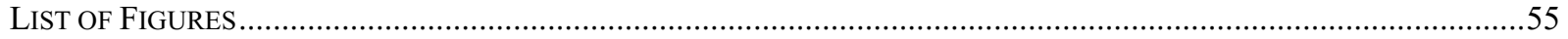

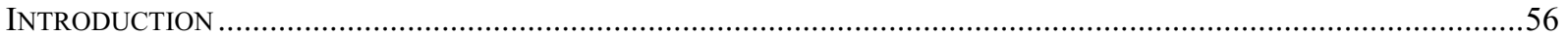

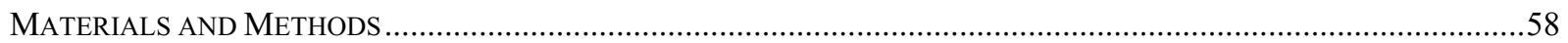

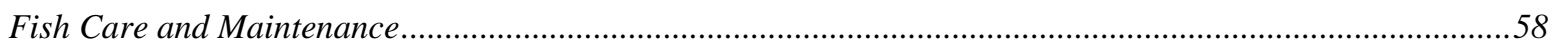

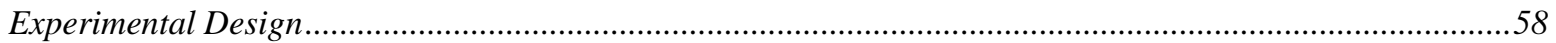

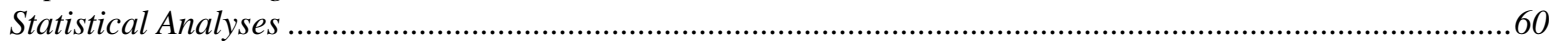

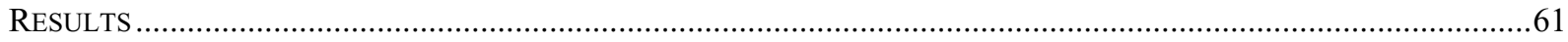

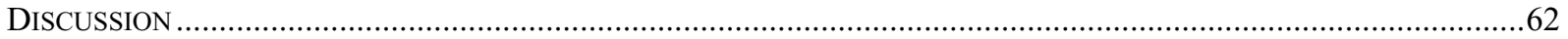

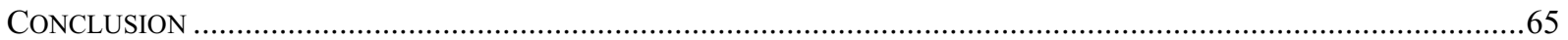

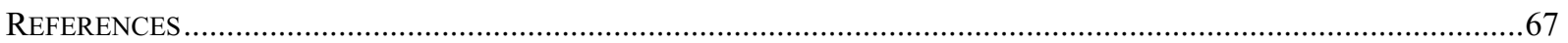

Tables

Table 1. Plasma glucose values from arctic char for each transport treatment and sampling time..................71

Table 2. Plasma chloride values from arctic char for each transport treatment and sampling time.................72 Figures

Figure 1. Percent hematocrit in arctic char exposed for $5.5 \mathrm{~h}$ to four transport treatments .........................73

Figure 2. Plasma cortisol in arctic char exposed for $5.5 \mathrm{~h}$ to four transport treatments.................................74

Figure 3. Plasma lactate in arctic char exposed for $5.5 \mathrm{~h}$ to four transport treatments..................................75

Appendices

Appendix A. Water quality values (mean \pm SEM) from each hour, with the exception of total ammonianitrogen (TAN) which was measured only at $5.5 \mathrm{~h}$, and treatment for the $5.5 \mathrm{~h}$ transport experiment. 
Chapter 1: Effects of Nitrite and Carbon Dioxide in Rainbow Trout (Oncorhynchus mykiss): Survival and Physiological Responses 


\begin{abstract}
Effects of Nitrite and Carbon Dioxide in Rainbow Trout (Oncorhynchus mykiss): Survival and Physiological Responses
\end{abstract}

\title{
Christopher D. Nelson
}

\begin{abstract}
West Virginia's Appalachian landscape encourages development of smaller, intensive aquaculture systems rather than the traditional, expansive earthen ponds found further south. Intensive aquaculture systems, especially recirculating and those using oxygen injection technologies, create new and unique water chemistry characteristics not found in traditional flow through and pond culture systems. Higher loading rates can enhance and increase production; however, they also can result in increased accumulation of metabolic by-products (i.e. carbon dioxide, ammonia, and nitrite) in the grow-out system. Expansion of aquaculture in West Virginia may create a unique challenge where both environmental carbon dioxide $\left(\mathrm{CO}_{2}\right)$ and nitrite $\left(\mathrm{NO}_{2}{ }^{-}\right)$are elevated to toxic levels due to the use of oxygen injection and recirculating aquaculture technologies. While there is some understanding of how each of these parameters independently affects fish, there is no information as to how these parameters interact in intensively cultured fish systems when elevated simultaneously. Therefore, the objective of the present study was to evaluate the survival and physiological responses of rainbow trout when exposed to $\mathrm{CO}_{2}$ and $\mathrm{NO}_{2}$. Three preliminary and two primary experiments were conducted. The two primary experiments were; 1) 96-h exposure of rainbow trout to $\mathrm{NO}_{2}{ }^{-}$and three levels of $\mathrm{CO}_{2}$ and 2) 96-h exposure of rainbow trout to $\mathrm{NO}_{2}^{-}$, chloride $\left(\mathrm{Cl}^{-}\right)$, and three levels of $\mathrm{CO}_{2}$. During experiments, rainbow trout survival and their physiological responses (hematocrit, plasma nitrite, glucose, lactate, and chloride) were quantified. Results indicate that $\mathrm{NO}_{2}{ }^{-}$ toxicity is affected by elevations in environmental $\mathrm{CO}_{2}$, and conversely, $\mathrm{CO}_{2}$ tolerance is affected by environmental $\mathrm{NO}_{2}{ }^{-}$concentrations. Additional experiments examining the interacting effects of $\mathrm{NO}_{2}{ }^{-}$and $\mathrm{CO}_{2}$ on fish are needed to identify the physiological mechanisms or effects that lead to increased $\mathrm{NO}_{2}$ and $\mathrm{CO}_{2}$ toxicities in fish.
\end{abstract}




\section{List of Tables}

Table 1. Blood and plasma parameters (mean \pm SEM) of rainbow trout Oncorhynchus mykiss) from experiment 1 .

Table 2. Blood and plasma parameters (mean $\pm \mathrm{SEM}$ ) of rainbow trout (Oncorhynchus mykiss) from experiment 2.

Table 3. Blood and plasma parameters (mean \pm SEM) of rainbow trout (Oncorhynchus mykiss) from experiment 3.

Table 4. Blood and plasma parameters (mean \pm SEM) of rainbow trout (Oncorhynchus mykiss) from experiment 4.

Table 5. Blood and plasma parameters (mean \pm SEM) of rainbow trout (Oncorhynchus mykiss) from experiment 5. 


\section{List of Figures}

Figure 1. Percent mortality of rainbow trout exposed for $24 \mathrm{~h}$ to environmental nitrite-N.

Figure 2. Plasma nitrite (mean $\pm \mathrm{SEM}$ ) in rainbow trout exposed for $24 \mathrm{~h}$ to increasing concentrations of environmental nitrite-N. Dashed line represents equal concentration of nitrite-N in the plasma and environment. Same lower case letters indicate no significant difference. $\mathrm{n}=15$ unless otherwise indicated on figure.

Figure 3. Plasma chloride (mean $\pm \mathrm{SEM}$ ) in rainbow trout exposed for $24 \mathrm{~h}$ to increasing concentrations of environmental nitrite-N. Same lower case letters indicate no significant difference. $\mathrm{n}=15$ unless otherwise indicated on figure.

Figure 4. Percent mortality of rainbow trout exposed for $96 \mathrm{~h}$ to environmental nitrite-N.

Figure 5. Plasma nitrite (mean $\pm \mathrm{SEM}$ ) in rainbow trout exposed for $96 \mathrm{~h}$ to increasing concentrations of environmental nitrite-N. Dashed line represents equal concentrations of nitrite- $\mathrm{N}$ in the plasma and environment. Same lower case letters indicate no significant difference. $n=15$ unless otherwise indicated on figure.

Figure 6. Percent survival of rainbow trout exposed for $96 \mathrm{~h}$ to a lethal level of nitrite-N to increasing concentrations of environmental chloride. Each treatment, except freshwater control, contained a lethal level $(9.03 \pm 0.04 \mathrm{mg} / \mathrm{L})$ of nitrite-N.

Figure 7. Plasma nitrite (mean $\pm \mathrm{SEM}$ ) in rainbow trout exposed for $96 \mathrm{~h}$ to a lethal level of nitrite- $\mathrm{N}$ in increasing concentrations of environmental chloride. Each treatment, except freshwater control, contained a lethal level $(9.03 \pm 0.04 \mathrm{mg} / \mathrm{L})$ of nitrite-N. Same lower case letters indicate no significant difference. $n=15$ unless otherwise indicated on figure. 
Figure 8. Plasma lactate (mean $\pm \mathrm{SEM}$ ) in rainbow trout exposed for $96 \mathrm{~h}$ to a lethal level of nitrite-N in increasing concentrations of environmental chloride. Each treatment, except freshwater control, contained a lethal level $(9.03 \pm 0.04 \mathrm{mg} / \mathrm{L})$ of nitrite-N. Same lower case letters indicate no significant difference. $n=15$ unless otherwise indicated on figure.

Figure 9. Percent mortality of rainbow trout exposed for $96 \mathrm{~h}$ to increasing concentrations of environmental nitrite- $\mathrm{N}$ and carbon dioxide.

Figure 10. Percent survival of rainbow trout exposed for $96 \mathrm{~h}$ to a lethal level of nitrite-N to increasing concentrations of environmental chloride and carbon dioxide. Each treatment, except freshwater control, contained a lethal level $(9.60 \pm$ $0.06 \mathrm{mg} / \mathrm{L}$ ) of nitrite-N.

Figure 11. Plasma nitrite (mean $\pm \mathrm{SEM}$ ) in rainbow trout exposed for $96 \mathrm{~h}$ to a lethal of nitrite- $\mathrm{N}$ in increasing concentrations of environmental chloride and carbon dioxide. Each treatment, except freshwater control, contained a lethal level $(9.60 \pm 0.06 \mathrm{mg} / \mathrm{L})$ of nitrite-N.

Figure 12. Plasma chloride (mean $\pm \mathrm{SEM}$ ) in rainbow trout exposed for $96 \mathrm{~h}$ to a lethal of nitrite- $\mathrm{N}$ in increasing concentrations of environmental chloride and carbon dioxide. Each treatment, except freshwater control, contained a lethal level $(9.60 \pm 0.06 \mathrm{mg} / \mathrm{L})$ of nitrite-N. 


\section{Introduction}

\section{West Virginia Aquaculture Industry}

Recent expansions in aquaculture characterize it as one of the fastest growing segments

of the U.S. agricultural sector. Expansion has been facilitated by increased production of many important aquatic species including catfish, salmon, trout, tilapia, shrimp, oysters, and crawfish (NASS 1998). Through the 1980's, the U.S. aquaculture industry increased four fold to a farm value of $\$ 762$ million by 1990 . In 1998 , the U.S. aquaculture industry was valued at nearly $\$ 1$ billion; however, seafood imports still represent the country's second largest non-combustible trade deficit (NASS 1998; FAO 2002). Thus, despite rapid growth of the industry, there is still demand for even more seafood products.

West Virginia may provide an ideal opportunity for expansion of the U.S. aquaculture industry. West Virginia's economy has experienced major structural changes over the past two decades with declines in the traditional industrial base (e.g., coal, primary metals, and chemicals) leading to a reduction in economic growth and double-digit unemployment rates (WVBEP 2003). The role of agriculture in the future economic development of the state is unclear because West Virginia agriculture is dominated by small part-time farmers and the rough terrain is unsuitable for highly mechanized, intensive, and large-scale operations (Vanderpool et al. 1993). However, West Virginia has an abundance of land and water supplies suitable for commercial aquaculture production (Jenkins and Hankins 1996). Thus, aquaculture may provide an opportunity for farm and industry diversification and offer promise for strengthening the state's agricultural sector (Vanderpool et al. 1993). Abundant water supplies as well as the increased demand for seafood products favor expansion of the industry throughout the state. 
The mountainous terrain of West Virginia's Appalachian landscape encourages development of smaller, intensive aquaculture systems rather than the traditional, expansive earthen ponds found further south. Intensive aquaculture systems, especially recirculating and those using oxygen injection technologies, create new and unique water chemistry characteristics not found in traditional flow through and pond culture systems. For example, use of oxygen injection eliminates dissolved oxygen as a limiting factor in fish culture, thereby allowing more fish to be stocked into the same volume of water, resulting in higher loading rates (Summerfelt et al. 2000). Higher loading rates can enhance and increase production; however, they also can result in increased accumulation of metabolic by-products (i.e. carbon dioxide, ammonia, and nitrite) in the grow-out system when combined with lower water exchange rates.

\section{Carbon Dioxide Challenges in the WV Aquaculture Industry}

Free carbon dioxide $\left(\mathrm{CO}_{2}\right)$ is one by-product produced by fish that may accumulate to toxic levels in intensive systems. Carbon dioxide is a gas that easily dissolves in water, and may accumulate even when concentrations in the surrounding air may be negligible (Boyd 1979). Once $\mathrm{CO}_{2}$ is expired by fish into water, accumulation of $\mathrm{CO}_{2}$ depends on a variety of factors including rate of production, water exchange rate, aeration technology, and buffering capacity of the water (Smart 1981; Summerfelt 2001).

In addition to production and release of $\mathrm{CO}_{2}$ by fish, West Virginia also faces environmental challenges such as regionally elevated concentrations of free $\mathrm{CO}_{2}$ in the water. Many watersheds in West Virginia are susceptible to high levels of $\mathrm{CO}_{2}$ because of karst topography of the region (Kozar et al. 1991). Spring or bore-hole water supplies are those typically associated with high levels of free $\mathrm{CO}_{2}$ (Smart 1981) and can routinely exceed $50 \mathrm{mg} / \mathrm{L}$ $\mathrm{CO}_{2}$ in Appalachian spring waters (Kozar et al. 1991; Hainly and Looper 1995). 
Elevated $\mathrm{CO}_{2}$ levels can present potential physiological problems and harmful effects to fish. High $\mathrm{CO}_{2}$ levels lower water $\mathrm{pH}$ and can limit the capacity of the fish's blood to carry oxygen by lowering blood pH at the fish's gills (Eddy et al. 1977; Wurts and Durborow 1992). Oxygen transport in salmonids can become impaired when environmental $\mathrm{CO}_{2}$ concentrations reach $20 \mathrm{mg} / \mathrm{L}$ (Wedemeyer 1996). In addition, high concentrations of $\mathrm{CO}_{2}$ can result in acidosis, hypercapnia, sedation, or death (Summerfelt 2000), as well as reduce fish growth, decrease food conversion ratios, lower condition factors, and reduce hematocrit and plasma chloride concentrations (Smart 1981; Danley 2001). Therefore, thoroughly understanding the effects of $\mathrm{CO}_{2}$ on fish health and productivity is important to the development of the West Virginia aquaculture industry.

\section{Nitrite Toxicity in the Aquaculture Industry}

In intensive aquaculture systems, water quality issues are rarely regulated to an isolated chemical change. For example, with the production of $\mathrm{CO}_{2}$ also comes the production of nitrogenous compounds such as ammonia and nitrite. Ammonia, the primary nitrogenous waste of fish, is oxidized into nitrite by the Nitrosomonas bacteria and further to the relative harmless nitrate ion by the Nitrobacter species (Rodriguez-Moreno and Tarazona 1994; Vedel et al. 1998). Nitrite can be problematic in recirculating systems because it is constantly generated and may accumulate when water is recycled (Russo et al. 1981; Timmons et al. 2001). Increased nitrite concentrations may cause harmful effects to fish such as decreased growth and survival (Perrone and Meade 1977; Colt et al. 1981; Tomasso 1994).

Unlike $\mathrm{CO}_{2}$, which has received abundant research attention in both human medicine and aquatic animal production sectors, the mechanisms behind nitrite toxicity are complex and not thoroughly understood. Nitrite is thought to be transported across the gill membrane of the fish 
by the mechanism that normally transports chloride ions (Perrone and Meade 1977; Tomasso 1994). In some species of fish, the transport process across the gills allows nitrite to concentrate in the blood relative to the concentration in the environment (Williams and Eddy 1988; Tomasso 1994). Accordingly, the toxicity of nitrite varies widely among species (Russo and Thurston 1977; Palachek and Tomasso 1984; Mazik et al. 1991; Atwood et al. 2001), with salmonids being most susceptible and eels being least susceptible (Williams and Eddy 1988).

The most recognized toxic effect of nitrite in the blood is the conversion of hemoglobin to methemoglobin. This process results in the oxidization of iron in the hemoglobin molecule from the ferrous (+2) to the ferric (+3) state (Tomasso 1994; Timmons et al. 2001), which is unable to bind or transport oxygen (Wedemeyer and Yasutake 1978; Tomasso 1994). Although methemoglobinemia is an obvious effect of nitrite, other possible toxic mechanisms may exist including gill and tissue damage, and liver hypoxemia (Crawford and Allen 1977; Arillo et al. 1984; Scarano and Saroglia 1984; Tomasso 1994).

Many studies have shown that the toxicity of nitrite can be ameliorated by specific environmental ions (Crawford and Allen 1977; Perrone and Meade 1977; Russo and Thurston 1977; Palachek and Tomasso 1984). Environmental chloride appears to be the most important ameliorating ion, although other ions such as calcium may also have beneficial effects (Tomasso 1994). Environmental chloride may reduce nitrite toxicity through a competitive interaction for the chloride transport mechanism at the gills (Perrone and Meade 1977; Tomasso 1994) given that nitrite and chloride are both monovalent anions and are similar in size and shape (Tomasso 1994).

The absorption of environmental nitrite by different fish species may reflect the inability of branchial chloride cells to discriminate chloride from nitrite ions (Tomasso 1994). Studies 
have shown that the most susceptible species to nitrite toxicity also have the highest chloride uptake rates, while low chloride uptake rates are characteristic of more tolerant species (Williams and Eddy 1988). Furthermore, the presence of elevated environmental chloride has been shown to lower plasma nitrite concentrations during environmental nitrite exposure (Palchek and Tomasso 1984; Mazik et al. 1991; Eddy et al. 1983). Therefore, the greater the environmental chloride:nitrite ratio, the lower the plasma nitrite concentrations (Tomasso 1994). Recognition of this relationship has resulted in the use of salts as a means of alleviating nitrite toxicity in fish caused by high environmental nitrite concentrations.

Nitrite and $\mathrm{CO}_{2}$ challenges in the West Virginia Aquaculture Industry

Expansion of aquaculture in West Virginia may create a unique challenge where both environmental $\mathrm{CO}_{2}$ and nitrite are elevated to toxic levels due to the use of oxygen injection and recirculating aquaculture technologies (Summerfelt et al. 2000). While there is some understanding of how each of these parameters independently affects fish, there is no information as to how these parameters interact in intensively cultured fish systems when elevated simultaneously. Indirect evidence suggests nitrite toxicity may be affected by elevations in $\mathrm{CO}_{2}$, since both nitrite and $\mathrm{CO}_{2}$ influence chloride homeostasis (Cameron and Iwama 1989; Tomasso 1994). During hypercapnia, acid-base disturbances in the blood appear to be partially compensated by decreasing the influx of chloride, with an associated increase of bicarbonate levels (Cameron and Iwama 1989). Goss et al. (1994a, 1994b) has demonstrated that the reduction in chloride flux across the gill is the result of gill remodeling, where fewer chloride cells, and thus branchial $\mathrm{Cl}^{-} / \mathrm{HCO}_{3}{ }^{-}$exchangers, are exposed to the water for ion exchange. 
If nitrite competes with chloride for entrance at the branchial $\mathrm{Cl}^{-} / \mathrm{HCO}_{3}{ }^{-}$exchanger in the gill, then the possibility exists that nitrite uptake could be reduced by hypercapnia since chloride uptake rates will be reduced. Jensen et al. (2000) observed this in freshwater crayfish (Astacus astacus). Alternatively, the combined effects of hypercapnia and elevated nitrite may be additive and negative, since they affect different aspects of the same physiological systems (respiratory and ionic balance). The two possible $\mathrm{CO}_{2} \mathrm{x}$ nitrite interactions hypothesized above (beneficial vs. toxic effects of $\mathrm{CO}_{2}$ and nitrite) would be important and have very different management implications. To facilitate aquaculture expansion in West Virginia, it is important to understand which of the two possible $\mathrm{CO}_{2} \mathrm{x}$ nitrite interactions may occur. Considering the work of Jensen et al. (2000), it was hypothesized that the reduced nitrite uptake rates seen in crayfish would also occur in rainbow trout, thereby reducing plasma nitrite concentrations and increasing survival.

Therefore, the objective of the present study was to evaluate the survival and physiological responses of rainbow trout when exposed to $\mathrm{CO}_{2}$ and nitrite. Three preliminary and two primary experiments were conducted. The two primary experiments were; 1) 96-h exposure of rainbow trout to nitrite and three levels of $\mathrm{CO}_{2}$ and 2) 96-h exposure of rainbow trout to nitrite, chloride, and three levels of $\mathrm{CO}_{2}$.

\section{Materials and Methods}

\section{$\underline{\text { Fish Care and Maintenance }}$}

Rainbow trout were raised at the Conservation Fund's Freshwater Institute, Shepherdstown, WV. Fish were housed in 1200-L fiberglass tanks supplied with oxygeninjected spring water (temperature $13.2 \pm 0.2^{\circ} \mathrm{C}$; dissolved oxygen $13.3 \pm 0.2 \mathrm{mg} / \mathrm{L} ; \mathrm{pH} 7.6 \pm$ 0.1 ; total alkalinity $241.7 \pm 4.6 \mathrm{mg} / \mathrm{L}$; calcium hardness $237.4 \pm 2.3 \mathrm{mg} / \mathrm{L}$ and $11.7 \pm 0.7 \mathrm{mg} / \mathrm{L}$ free $\mathrm{CO}_{2}$ ). Photoperiod was maintained on a $14 \mathrm{~h}: 10 \mathrm{~h}$, light:dark cycle. Fish were fed daily by 
automatic feeders with commercial feed (Melick Aquafeed, Catawissa, PA), and they were fasted $24 \mathrm{~h}$ before stocking, and throughout the experiments, unless otherwise described. Water temperature, dissolved oxygen, and $\mathrm{pH}$ were measured daily, while total alkalinity, calcium hardness, free $\mathrm{CO}_{2}$, and total ammonia-nitrogen (TAN) were measured weekly in the holding tanks using commercially available equipment and test kits described below.

\section{Experimental Conditions}

Rainbow trout were randomly selected from the holding tanks and stocked into 68-L polypropylene tanks at $48 \mathrm{~h}$ before the start of the experiments ( 5 fish per tank). The number of tanks used varied with experiments and are described below with the appropriate experiment. Temperature, dissolved oxygen, $\mathrm{pH}, \mathrm{TAN}$, and nitrite were measured every 24-h in each of the tanks throughout the experiments using handheld meters (YSI Models 58, 95, or 60/10 FT Yellow Springs, $\mathrm{OH}$ ) and standard tests kits (Hach Company, Loveland, CO). Total alkalinity and calcium hardness were measured twice during each experiment (Hach Company, Loveland, CO). Free $\mathrm{CO}_{2}$ and chloride concentrations also were measured when appropriate (Hach Company, Loveland, CO and digital chloridometer Labconco, Lenexa, KS). Mean ( \pm SEM) water quality measurements from each experiment are provided in Appendix A.

At the beginning of each experiment $(0 \mathrm{~h})$, the appropriate amount of nitrite as sodium nitrite $\left(\mathrm{NaNO}_{2}\right)$ was added into the experimental tanks to obtain treatment concentrations (see Appendix B for calculations). Fish were continuously exposed to treatment concentrations throughout each experiment via static water baths or peristaltic drip. Nitrite treatment concentrations were confirmed using standard water quality test kits (Hach Company, Loveland, 
$\mathrm{CO})$. Chloride as sodium chloride $(\mathrm{NaCl})$ was added in a similar manner where applicable, and concentrations confirmed using a digital chloridometer (Labconco, Lenexa, KS).

After each 24-h exposure, dead fish were counted and removed from the tanks. Fish were considered deceased when no gill movement was visible. At the end of each experiment, all remaining live fish were anesthetized in a $0.02 \mathrm{mg} / \mathrm{L}$ solution of tricaine methanesulfonate (MS-222) and blood samples collected.

Blood was collected into lithium-heparinized syringes from vessels in the caudal peduncle (Houston 1990). Sampling was completed within 5 minutes of initial tank disturbance and each fish was bled only once. Blood was transferred into heparinized microhematocrit tubes and 3-ml glass tubes (Vacutainers ${ }^{\mathrm{TM}}$, Becton Dickinson \& Co., Sparks, Maryland, USA). Microhematocrit samples (in duplicate) were centrifuged for $5 \mathrm{~min}$ at 11,500 rpm and the percent hematocrit determined using a microhematocrit reader (IEC, Needham Heights, MA).

The whole blood that was collected into 3-ml glass tubes was centrifuged for $10 \mathrm{~min}$ at $3500 \mathrm{rpm}$, and the resulting plasma was transferred into $1.5-\mathrm{ml}$ polypropylene microcentrifuge tubes. Plasma samples were stored at -20 C until analyzed for nitrite, chloride, glucose, and lactate concentrations. Plasma $\mathrm{NO}_{2}{ }^{-}$concentrations were determined according to USEPA (1974) as modified by Palachek and Tomasso (1984). Overall percent recovery for the plasma nitrite assay was $95.64 \%$ (range of means $=93.0$ to $98.3 \%$, pooled $\mathrm{SEM}=1.7, \mathrm{n}=2$ per experiment). Plasma chloride was measured using a digital chloridometer (Labconco, Lenexa, KS) and glucose and lactate by a digital glucose/lactate analyzer (2300 Select, YSI Inc., Yellow Springs, $\mathrm{OH})$. 


\section{Experimental Design}

Preliminary experiments 1 through 3 were conducted under static conditions, using 68.1L polypropylene tanks filled with $45 \mathrm{~L}$ of water. Experimental tanks were partially submerged in a larger flow-through water bath to maintain constant water temperature. Approximately 50\% of the water in each experimental tank was exchanged daily to minimize accumulation of metabolic waste. Dissolved oxygen concentrations were maintained by supplemental aeration. The median lethal concentration $\left(\mathrm{LC}_{50}\right)$ was calculated for experiments 1 and 2 by the trimmed SpearmanKarber method (Hamilton et al. 1977), while a percent survival was determined for experiment 3. Experiments 1 through 3 served as preliminary experiments to obtain baseline data (e.g., nitrite and chloride concentrations, fish survival) necessary to conduct the primary experiments 4 and 5 . Experiments 4 and 5 were conducted under flow-through conditions in the 68.1-L polypropylene tanks (containing 45-L of water). Nitrite treatments were maintained using a peristaltic pump which continuously dripped an appropriate concentrated stock solution into the flow-through experimental tanks.

\section{Experiment 1: 24-h $\mathrm{LC}_{50} \underline{\text { with } \mathrm{NO}_{2}} \underline{\underline{ }}^{-}$}

Seven concentrations of $\mathrm{NO}_{2}^{-}(3.6 \pm 0.5,7.1 \pm 1.5,13.2 \pm 2.0,20.9 \pm 3.0,28.6 \pm 1.2,59.4$ \pm 13.8 , and $\left.108.1 \pm 16.4 \mathrm{mg} / \mathrm{L} \mathrm{NO}_{2}-\mathrm{N}\right)$, along with a control $\left(0.4 \pm 0.5 \mathrm{mg} / \mathrm{L} \mathrm{NO}_{2}-\mathrm{N}\right)$, were tested in triplicate for a total of 24 tanks. At the beginning of the experiment the appropriate amount of nitrite was pre-dissolved and added into each tank. Rainbow trout, $179.4 \pm 3.7 \mathrm{~g}$ and $21.7 \pm 0.2 \mathrm{~cm}$ long, were exposed for $24-\mathrm{h}$ to the treatment concentrations. At the end of the experiment, blood samples were collected from all remaining live fish and the $\mathrm{LC}_{50}$ determined as previously described. 


\section{Experiment 2: $96-\mathrm{h} \mathrm{LC} \underline{50} \underline{\text { with } \mathrm{NO}_{2}}{ }^{-}$}

Eight nitrite concentrations $(1.4 \pm 0.05,1.6 \pm 0.06,2.1 \pm 0.06,3.2 \pm 0.09,4.7 \pm 0.14,6.5$ $\pm 0.10,9.3 \pm 0.19$, and $\left.13.3 \pm 0.18 \mathrm{mg} / \mathrm{L} \mathrm{NO}_{2}-\mathrm{N}\right)$, along with a control $\left(0.5 \pm 0.08 \mathrm{mg} / \mathrm{L} \mathrm{NO} \mathrm{N}_{2}-\mathrm{N}\right)$, were tested in triplicate for a total of 27 tanks. At the beginning of the experiment the appropriate amount of nitrite was pre-dissolved and added into each tank. Rainbow trout, 201.9 $\pm 5.6 \mathrm{~g}$ and $23.5 \pm 0.24 \mathrm{~cm}$ long, were exposed for $96-\mathrm{h}$ to the treatment concentrations. At the end of the experiment, blood samples were collected from remaining live fish, and the $\mathrm{LC}_{50}$ was determined as previously described.

Experiment 3: 96-h with $\mathrm{NO}_{2}^{-}+\mathrm{Cl}^{-}$

Eight concentrations of $\mathrm{Cl}^{-}(20.4 \pm 0.18,24.1 \pm 0.17,28.3 \pm 0.25,35.7 \pm 0.21,48.0 \pm$ $0.33,67.5 \pm 0.46,100.0 \pm 0.48$, and $\left.165.2 \pm 6.6 \mathrm{mg} / \mathrm{L} \mathrm{Cl}^{-}\right)$were tested in combination with a single, lethal concentration of nitrite $\left(9.03 \pm 0.04 \mathrm{mg} / \mathrm{L} \mathrm{NO}_{2}-\mathrm{N}\right)$. A freshwater control and a nitrite-only control also were tested. All treatment combinations were replicated three times for a total of 30 tanks. At the beginning of the experiment the appropriate amount of nitrite and $\mathrm{Cl}^{-}$ were pre-dissolved and added to each tank. Rainbow trout, $226.7 \pm 4.9 \mathrm{~g}$ and $24.8 \pm 0.21 \mathrm{~cm}$ long, were exposed for 96-h to the lethal nitrite and chloride concentrations. At the end of the experiment, blood samples were collected from remaining live fish as previously described, and percent survival was calculated.

Experiment 4: $\mathrm{CO}_{2} \underline{\times N O}_{2}^{-}$ 
Two concentrations of $\mathrm{NO}_{2}^{-}\left(0.84 \pm 0.03\right.$ and $\left.2.1 \pm 0.03 \mathrm{mg} / \mathrm{L} \mathrm{NO}_{2}-\mathrm{N}\right)$, along with a control $\left(0.08 \pm 0.02 \mathrm{mg} / \mathrm{L} \mathrm{NO}_{2}-\mathrm{N}\right)$, were tested with three $\mathrm{CO}_{2}$ levels $(9.0 \pm 0.27,13.8 \pm 0.76$, and $23.4 \pm 1.0 \mathrm{mg} / \mathrm{L}$ free $\left.\mathrm{CO}_{2}\right)$ in duplicate for a total of 14 tanks. Rainbow trout, $270.1 \pm 7.6 \mathrm{~g}$ and $25.7 \pm 0.25 \mathrm{~cm}$ long, were initially stocked into 500-L flow-through tanks equipped with $\mathrm{CO}_{2}$ diffusers, and allowed to acclimate to the respective $\mathrm{CO}_{2}$ treatments for two weeks before the start of the experiment. The $\mathrm{CO}_{2}$ concentrations were maintained using micro pore diffusers (MBD 75 s A grade, Point Four Systems Inc., Port Moody, British Columbia, Canada) and gas flow meters (Key Instruments, Trevose, PA). The entire system was connected by polyethylene tubing to a remote liquid $\mathrm{CO}_{2}$ cylinder (Messler MG Industries, Malvern, $\mathrm{PA}$ ). During $\mathrm{CO}_{2}$ acclimation, fish were fed during week 1, but were fasted during week 2 .

After the two week acclimation period, fish were stocked into experimental tanks. Experimental tanks were also equipped with $\mathrm{CO}_{2}$ diffusers connected to a liquid $\mathrm{CO}_{2}$ tank. Carbon dioxide treatments were randomly assigned among the experimental tanks, and water $\mathrm{CO}_{2}$ concentrations were adjusted to match those of the $\mathrm{CO}_{2}$ acclimation tanks before fish were stocked. Thus, when fish were moved from the $\mathrm{CO}_{2}$ acclimation tanks into experimental tanks, $\mathrm{CO}_{2}$ treatments were maintained. Fish were acclimated to the experimental tanks for $48 \mathrm{~h}$ before the experiment was started.

At the beginning of the experiment, the appropriate amount of nitrite was pre-dissolved and added into each tank to initially reach target concentrations. Treatment concentrations were thereafter maintained via the peristaltic pump and concentrated stock solutions. Free $\mathrm{CO}_{2}$ treatments were checked daily via the $\mathrm{CO}_{2}$ nomogram method (APHA 1998). In addition, the nomogram method was validated by titrating water samples from selected tanks at each $\mathrm{CO}_{2}$ treatment level. Titrations were completed using a hand-held digital titrator (Hach Company) 
and a bench top pH meter (Accumet Model 915, Fisher Scientific, Pittsburgh, PA) equipped with a G-P Gel combo pH electrode (Corning Incorporated, Corning, NY). Fish were exposed to the treatments for 96-h, with survival quantified every $24 \mathrm{~h}$. At the end of the experiment, blood samples were collected from remaining live fish as previously described.

\section{Experiment 5: $\mathrm{CO}_{2} \underline{\times ~ N O}_{2}^{-}{ }^{-} \times \mathrm{Cl}^{-}$}

A single lethal nitrite concentration $\left(9.6 \pm 0.06 \mathrm{mg} / \mathrm{L} \mathrm{NO}_{2}-\mathrm{N}\right)$, along with controls, was tested in combination with three $\mathrm{CO}_{2}$ levels $(7.7 \pm 0.43,14.8 \pm 0.74$, and $29.3 \pm 1.96 \mathrm{mg} / \mathrm{L}$ free $\left.\mathrm{CO}_{2}\right)$ and two $\mathrm{Cl}^{-}$levels $\left(48.0 \pm 1.75\right.$ and $\left.109.7 \pm 1.39 \mathrm{mg} / \mathrm{L} \mathrm{Cl}^{-}\right)$in duplicate for a total of 16 tanks. Acclimation and experimental conditions were similar to those described for experiment 4. Rainbow trout, $311.9 \pm 11.3 \mathrm{~g}$ and $26.5 \pm 0.34 \mathrm{~cm}$ long were exposed to tank conditions for 96-h. At the end of the experiment, blood samples were collected from remaining live fish as previously described.

\section{$\underline{\text { Statistical Analyses }}$}

Treatments were compared using individual fish responses and multiple ANOVA (Proc GLM) procedures. Results are presented as treatment means \pm standard error of the mean (SEM). Following ANOVA testing, significant differences were further analyzed by Duncan's multiple comparison procedures and correlation used to determine linear relationships. The alpha level $(\alpha)$ of significance for all tests was 0.05 . Statistical analyses were completed using Microsoft Excel (Excel XP, Microsoft Co., Redmond, CA) and SAS (SAS 8.2, SAS Inst., Cary, NC). 


\section{Results}

\section{Experiment 1: 24-h $\mathrm{LC}_{50} \underline{\text { with } \mathrm{NO}_{2}} \underline{\underline{ }}^{-}$}

Rainbow trout mortality showed a dose-dependent response to nitrite-N concentrations. Mortality was observed in $7.1 \mathrm{mg} / \mathrm{L}$ and higher nitrite-N treatments (Fig. 1). Total mortality (100\%) was observed in the 28.6 and higher $\mathrm{mg} / \mathrm{L}$ nitrite-N treatments. No control fish died during the experiment. The $24-\mathrm{h} \mathrm{LC}_{50}$ was $8.68 \mathrm{mg} / \mathrm{L}$ nitrite-N $(95 \% \mathrm{CI}=7.30$ to $12.85 \mathrm{mg} / \mathrm{L}$ nitrite-N).

Plasma nitrite increased significantly with increasing environmental nitrite and was linearly related $\left(r^{2}=0.96\right.$; Fig. 2$)$. Plasma nitrite was significantly different from the control at environmental nitrite- $\mathrm{N}$ concentrations of $3.6 \mathrm{mg} / \mathrm{L}$ and higher. Plasma chloride was inversely correlated to environmental nitrite- $\mathrm{N}$ concentrations $\left(\mathrm{r}^{2}=-0.85\right)$ and decreased with increasing environmental nitrite (with the exception of the $7.1 \mathrm{mg} / \mathrm{L}$ nitrite-N concentration; Fig. 3).

Plasma chloride differed significantly $(\mathrm{p}<0.005)$ compared to controls at $20.9 \mathrm{mg} / \mathrm{L}$

environmental nitrite-N level. Percent hematocrit was significantly different $(p=0.04)$ in the 7.1 and $20.9 \mathrm{mg} / \mathrm{L}$ nitrite-N treatment groups compared to the control (Table 1). No linear relationship was detected between hematocrit and environmental nitrite-N. Plasma glucose or lactate differences were not detected among treatments (Table 1).

\section{Experiment 2: 96-h $\mathrm{LC}_{50} \underline{\text { with }} \underline{\mathrm{NO}_{2}} \underline{2}^{-}$}

Rainbow trout mortality showed a dose-dependent response to nitrite-N concentration. Mortality was observed at $2.1 \mathrm{mg} / \mathrm{L}$ and higher nitrite-N concentrations (Fig. 4). Total mortality $(100 \%)$ was observed in the 6.5 and higher $\mathrm{mg} / \mathrm{L}$ nitrite-N treatments. No control fish died 
during the exposure. The $96-\mathrm{h} \mathrm{LC}_{50}$ was $2.96 \mathrm{mg} / \mathrm{L}$ nitrite-N $(95 \% \mathrm{CI}=2.64$ to $3.31 \mathrm{mg} / \mathrm{L}$ nitrite-N).

Plasma nitrite increased with increasing environmental nitrite concentrations, with the exception of the 3.2 nitrite-N level, and these responses were linearly related $\left(\mathrm{r}^{2}=0.88\right.$; Fig. 5). Plasma nitrite concentrations for $\mathrm{NO}_{2}^{-}$treated fish, however, were not significantly different (with the exception of the $4.7 \mathrm{mg} / \mathrm{L}$ nitrite- $\mathrm{N} ; \mathrm{p}=0.01$ ) from those of the control. Overall glucose levels were significantly decreased in nitrite exposed fish compared to the control (Table 2). Plasma glucose was significantly different $(p=0.02)$ at $2.1 \mathrm{mg} / \mathrm{L}$ nitrite-N compared to all other treatments. Significant differences among treatments were not detected for hematocrit, plasma lactate, and chloride concentrations when compared to control values (Table 2).

\section{Experiment 3: 96-h with $\mathrm{NO}_{2}^{-}+\mathrm{Cl}^{-}$}

Supplemental environmental chloride increased survival of rainbow trout exposed $9.03 \pm$ $0.04 \mathrm{mg} / \mathrm{L}$ nitrite-N (Fig. 6). Survival was $>0 \%$ at $28.3 \mathrm{mg} / \mathrm{L}$ and higher chloride treatments. Survival reached $100 \%$ at the $165.2 \mathrm{mg} / \mathrm{L}$ chloride treatment (Fig. 6).

Addition of environmental chloride significantly decreased plasma nitrite among nitriteexposed fish in a dose-dependent manner (Fig. 7). Plasma lactate decreased with increasing environmental chloride (with the exception of the $35.7 \mathrm{mg} / \mathrm{L} \mathrm{NaCl}$ level) and a significant difference $(\mathrm{p}<0.005)$ among chloride treatments was detected (Fig. 8). Plasma glucose, plasma chloride, and hematocrit were not affected by treatments (Table 3). 


\section{$\underline{\text { Experiment 4: } \mathrm{CO}_{2}} \underline{\times ~ N O}_{2}^{-}$}

Mortality was observed in all $\mathrm{CO}_{2} \times \mathrm{NO}_{2}{ }^{-}$treatments. At $0.8 \mathrm{mg} / \mathrm{L}$ nitrite-N, mortality was significantly increased in the high $\mathrm{CO}_{2}$ treatment compared to the low and medium $\mathrm{CO}_{2}$ treatments. In the $2.1 \mathrm{mg} / \mathrm{L}$ nitrite- $\mathrm{N}$, treatment mortality increased from the low to medium $\mathrm{CO}_{2}$ treatment, and decreased from the medium to high $\mathrm{CO}_{2}$ treatment (Fig. 9). Mortality was higher in all of the $2.1 \mathrm{mg} / \mathrm{L}$ nitrite-N treatments compared to the $0.8 \mathrm{mg} / \mathrm{L}$ nitrite-N treatments. No significant differences were detected in hematocrit, plasma nitrite, glucose, lactate, or chloride concentrations among treatments (Table 4).

\section{$\underline{\text { Experiment 5: } \mathrm{CO}_{2}} \underline{\times \mathrm{NO}_{2}} \underline{2}^{-} \underline{\mathrm{x} \mathrm{Cl}}-$}

Supplemental environmental chloride (as $\mathrm{NaCl}$ ) increased survival of rainbow trout exposed to $9.60 \pm 0.06 \mathrm{mg} / \mathrm{L}$ nitrite-N (Fig. 10). Mortality was observed in all of the $\mathrm{CO}_{2} \times$ low $(48.0 \mathrm{mg} / \mathrm{L}) \mathrm{NaCl}$ treatments. Mortality was also observed in the medium $\mathrm{CO}_{2} \mathrm{x}$ high $(109.7$ $\mathrm{mg} / \mathrm{L}) \mathrm{NaCl}$ treatment.

Increased environmental chloride significantly decreased plasma nitrite levels in fish exposed to the lethal level of $9.60 \pm 0.06 \mathrm{mg} / \mathrm{L}$ nitrite-N (Fig. 11). A significant difference in plasma nitrite $(\mathrm{p}=0.04)$ was detected among environmental chloride treatments. There were no significant differences, however, observed in plasma nitrite among $\mathrm{CO}_{2}$ treatments or among chloride $\mathrm{x} \mathrm{CO}_{2}$ treatments. Plasma chloride was significantly different $(\mathrm{p}<0.005)$ among environmental chloride treatments but not among $\mathrm{CO}_{2}$ or chloride $\mathrm{x}_{2}$ treatments (Fig. 12). There were no significant differences in hematocrit, plasma glucose and plasma lactate concentrations (Table 5). 


\section{Discussion}

The independent effects of nitrite and $\mathrm{CO}_{2}$ on rainbow trout have been well documented (Russo and Thurston 1977; Eddy et al. 1983; Eddy et al. 1977; Iwama and Heisler 1991), but there is no information available on the interaction between nitrite and $\mathrm{CO}_{2}$ in fish. Because of known changes in chloride transport under conditions of hypercapnia (Goss et al. 1994a), we hypothesized that nitrite toxicity (mortality and plasma nitrite concentrations) would be reduced during hypercapnia; however, our results did not support this hypothesis. Instead, our results suggest increased toxicity to elevated nitrite $\mathrm{x}$ hypercapnia compared to either nitrite or elevated $\mathrm{CO}_{2}$ toxicity alone (Figs. 9 and 11).

\section{Nitrite Toxicity During Normocapnia}

Results from the preliminary (normocapnic) nitrite toxicity experiments $\left(24-\mathrm{h} \mathrm{LC}_{50}=\right.$ $8.68 \mathrm{mg} / \mathrm{L}$ and $96-\mathrm{h} \mathrm{LC}_{50}=2.96 \mathrm{mg} / \mathrm{L}$ nitrite-N) were similar to those observed by Eddy et al. 1983 (9.7 mg/L nitrite-N) and Russo and Thurston 1977 (0.2 mg/L nitrite-N), respectively. Minor differences in environmental nitrite tolerance may have resulted from water quality disparities among studies, such as higher $\mathrm{CO}_{2}$ concentrations in the water of the present study (average $\mathrm{CO}_{2}=12 \mathrm{mg} / \mathrm{L}$ ), and/or different fish sizes (Tomasso 1994). The linear relationship detected in the present study between plasma nitrite and environmental nitrite has been well documented elsewhere (Crawford and Allen 1977; Perrone and Meade 1977; Eddy et al. 1983). Plasma nitrite levels in the current study consistently exceeded environmental concentrations, supporting results of previous studies that showed rainbow trout actively transport nitrite from the environment to the blood (Tomasso et al. 1979; Tomasso 1986). During experiment 1, plasma chloride also decreased with increasing environmental nitrite. Williams and Eddy (1988) 
reported a similar inverse relationship between plasma chloride and environmental nitrite concentrations in fish.

Although significant hematocrit differences were detected among treatment groups in experiment one, all results were within the range reported as normal for rainbow trout (Barton 2000), and so it is not clear if the difference is meaningful. There was a slight decrease observed in plasma glucose at $2.1 \mathrm{mg} / \mathrm{L}$ nitrite-N during experiment two; however, plasma glucose levels were not significantly different compared to control levels in the higher environmental nitrite treatment groups. The reduction in plasma glucose levels may suggest that rainbow trout were experiencing stress-related toxicity responses.

Supplemental environmental chloride can alleviate the toxicity of nitrite in some fishes (Tomasso er al. 1979; Palachek and Tomasso 1984; Mazik et al. 1991), and results of experiment $3\left(\mathrm{NO}_{2}{ }^{-} \times \mathrm{Cl}^{-}\right)$are consistent with those of previous studies. Results of experiment 3 showed that rainbow trout simultaneously exposed to a lethal level of nitrite with increasing environmental chloride levels had correspondingly and significantly decreased plasma nitrite (Fig. 7). Percent survival also increased with increasing environmental chloride levels (Fig. 6). Russo et al. (1981) reported that the $96-\mathrm{LC}_{50}$ values of rainbow trout with chloride were an order of magnitude higher than those obtained without chloride. In experiment 3, approximately 165.2 $\mathrm{mg} / \mathrm{L} \mathrm{NaCl}$ was needed to observe $100 \%$ survival and $100 \mathrm{mg} / \mathrm{L} \mathrm{NaCl}$ to reduce plasma nitrite levels below environmental levels (Fig. 6), and these observations are consistent with results reported by Russo et al. (1981).

Physiologically, a significant decrease was observed in plasma lactate levels among nitrite exposed fish with increasing environmental chloride concentrations; whereas, plasma lactate values in the higher chloride treatments were similar to control levels. Such a relationship 
has not been documented previously. Results may indicate that trout at higher chloride treatments were experiencing less nitrite-induced stress (i.e. less burst-type swimming or escape behavior) than those at the lower chloride levels (Thomas et al. 1999). Decreased stress-related responses would be expected with decreased nitrite toxicity.

\section{Toxicity Responses to $\mathrm{CO}_{2}$ Only (No Nitrite)}

As expected, free $\mathrm{CO}_{2}$ concentrations used in experiments 4 and 5 did not cause mortality among control fish exposed only to $\mathrm{CO}_{2}$ (no nitrite). Other $\mathrm{CO}_{2}$ studies conducted at the Freshwater Institute also have demonstrated 100\% survival among rainbow trout chronically exposed to concentrations as high as $48 \mathrm{mg} / \mathrm{L}$ (or double the concentrations used in the current study; Danley 2001). Thus, all $\mathrm{CO}_{2}$ concentrations used in the current study were within a tolerable (100\% survival) range for rainbow trout.

Although not significant, plasma chloride concentrations also showed an expected decrease with increasing $\mathrm{CO}_{2}$ concentration at low or zero nitrite concentrations (Tables 4 and 5). Cameron and Iwama (1987) have documented a similar decrease in plasma chloride in channel catfish (Ictalurus punctatus) with increasing $\mathrm{CO}_{2}$.

\section{$\underline{\text { Toxicity Responses to } \mathrm{NO}_{2}-{ }^{-} \mathrm{CO}_{2}}$}

Increasing $\mathrm{CO}_{2}$ concentrations resulted in increasing mortality for both $\mathrm{NO}_{2}$ treatment groups of experiment 4 (with the exception of the $2.1 \mathrm{NO}_{2} \times 23 \mathrm{CO}_{2}$ treatment). Assuming $\mathrm{LC}_{50}$ 's are generally stable under normocapnic conditions, our results suggest that increasing both environmental nitrite and carbon dioxide simultaneously increases the toxicity of both water quality variables in fish. During experiment 2 , mortality was first observed at a nitrite treatment dose of $7.1 \mathrm{mg} / \mathrm{L}$ nitrite-N; however, during hypercapnia in experiment 4 , mortality was 
observed in nitrite treatments as low as $0.8 \mathrm{mg} / \mathrm{L}$ nitrite- $\mathrm{N}$, with mortality increasing in a dosedependent manner. Thus, fish appear to be less tolerant to environmental nitrite during hypercapnia than they otherwise might be.

Conversely, fish also appear to be less tolerant to environmental hypercapnia during exposure to elevated environmental nitrite (Figs. 9 and 11). As discussed previously, survival to environmental hypercapnia is usually high (Fivelstad et al. 1998; Danley 2000), with survival of approximately $100 \%$ at free $\mathrm{CO}_{2}$ levels of up to $48 \mathrm{mg} / \mathrm{L}$. During experiment 4 , the presence of $0.8 \mathrm{mg} / \mathrm{L}$ environmental nitrite resulted in a dose-dependent decrease in survival with increasing $\mathrm{CO}_{2}$ at concentrations that are usually otherwise tolerable (i.e. 0 vs. $30 \%$ mortality at $23.0 \mathrm{mg} / \mathrm{L}$ $\mathrm{CO}_{2}$ ). Plasma nitrite and chloride values indicated no consistent response to the $\mathrm{NO}_{2}{ }^{-} \times \mathrm{CO}_{2}$ treatments, although it is not clear why this occurred. The $\mathrm{CO}_{2} \times \mathrm{NO}_{2}$ mortality trend was also observed in experiment 5, for the low $\mathrm{Cl}^{-}$treatment group. High environmental chloride levels appeared to ameliorate the toxic effects of $\mathrm{NO}_{2}$, regardless of the $\mathrm{CO}_{2}$ concentration (survival was between 80 and $100 \%$ ) thus indicating that the nitrite $\mathrm{x} \mathrm{CO}_{2}$ toxicity may be ameliorated by salt treatment. Overall, it appears there is a negative and additive effect of $\mathrm{NO}_{2}$ and $\mathrm{CO}_{2}$ on rainbow trout survival, though it is yet unclear how these two variables interact physiologically within the fish to increase mortality.

The conclusions discussed above appear to be in direct contrast with results from the only other results available for $\mathrm{CO}_{2} \times \mathrm{NO}_{2}{ }^{-}$toxicity in aquatic organisms; Jensen et al. (2000) conducting a similar study in freshwater crayfish, observed a reduction in nitrite uptake during hypercapnia leading to the conclusion of reduced nitrite toxicity during hypercapnia. However, differences in experimental design and sampling method may explain the seemingly conflicting results. For example, one notable difference between the present study and Jensen et al. (2000) 
was that Jensen and colleagues did not use a $\mathrm{CO}_{2}$ acclimation period before exposing the crayfish to nitrite. According to Eddy et al. (1977), an acclimation period of approximately $24 \mathrm{~h}$ is needed to restore physiological conditions to a near steady-state level after acute exposure to a hypercapnic environment. Crayfish used by Jensen et al. (2000) may have been suffering from acute hypercapnic blood acidosis and other physiological changes in addition to the toxic effects of nitrite, a scenario less likely to occur in a relatively stable culture environment. Another important difference between the two studies was the times in which fish sampling occurred. Jensen et al. (2000) sampled crayfish at 0, 3, 24 and 48 h, whereas the present study only sampled at $96 \mathrm{~h}$. The sampling times of Jensen et al. (2000) could have possibly been too short to allow the blood of crayfish to reach a near steady state condition. From their results, prominent differences in plasma nitrite were observed at 24 and $48 \mathrm{~h}$ between the nitrite-only treatment and the nitrite with hypercapnia treatment; however, the differences between the treatments seem to decrease as time increases. If their experiment would have continued past 48 $\mathrm{h}$, the differences observed in plasma nitrite might have been minimal between the two treatments. In the present study, fish sampling occurred only at $96 \mathrm{~h}$. This time period could have produced results in which some level of equilibrium inside the fish had already been reached.

\section{Conclusions}

Intensive aquaculture systems, particularly recirculating and those using oxygen injections, have the potential for increased accumulation of metabolic by-products, especially nitrite and $\mathrm{CO}_{2}$. Results of the present study indicate nitrite toxicity is affected by elevations in environmental $\mathrm{CO}_{2}$, and conversely, $\mathrm{CO}_{2}$ tolerance is affected by environmental nitrite 
concentrations. Additional experiments examining the interacting effects of nitrite and $\mathrm{CO}_{2}$ on fish are needed to identify the physiological mechanisms or effects that lead to increased $\mathrm{NO}_{2} \mathrm{x}$ $\mathrm{CO}_{2}$ toxicities in fish. 


\section{References}

APHA (American Public Health Association), American Public Water Works Association, and Water Pollution Control Federation. 1998. Standard methods for the examination of water and wastewater. $20^{\text {th }}$ edition. Washington, D. C., USA.

Arillo, A., E. Gaino, C. Margiocco, P. Mensi, and G. Schenone. 1984. Biochemical and ultrastructural effects of nitrite in rainbow trout: liver hypoxia as the root of the acute toxicity mechanism. Environmental Research 34:135-154.

Atwood, H. L., J. R. Tomasso, and T. I. J. Smith. 2001. Nitrite toxicity to southern flounder Paralichthys lethostigma in fresh and brackish water. Journal of the World Aquaculture Society 32:348-351.

Barton, B. A. 2000. Stress. Pages 892-898 in R. R. Stickney, editor. Encyclopedia of Aquaculture. John Wiley \& Sons, Inc., New York, New York.

Boyd, C. E. 1979. Water quality in warmwater fish ponds. Agricultural Experiment Station, Auburn University, Auburn, Alabama. 359 pages.

Cameron, J., and G. Iwama. 1987. Compensation of progressive hypercapnia in channel catfish and blue crabs. Journal of Experimental Biology 133:183-197.

Cameron, J., and G. Iwama. 1989. Compromises between ionic regulation and acidbase regulation in aquatic animals. Canadian Journal of Zoology 67:3078-3084.

Colt, J., R. Ludwig, G. Tchobanoglous, and J. J. Cech. 1981. The effects of nitrite on the short-term growth and survival of channel catfish, Ictalurus punctatus. Aquaculture 8:209-224.

Crawford, R. E., and G. H. Allen. 1977. Seawater inhibition of nitrite toxicity to Chinook salmon. Transactions of the American Fisheries Society 106:105-109. 
Danley, M. L. 2001. Growth and physiological responses of rainbow trout to elevated carbon dioxide: chronic and acute challenges. Master's thesis. West Virginia University, Morgantown, West Virginia.

Eddy, F. B., J. P. Lomholt, R. E. Weber, and K. Johansen. 1977. Blood respiratory properties of rainbow trout (Salmo gairdneri) kept in water of high $\mathrm{CO}_{2}$ tension. Journal of Experimental Biology 67:37-47.

Eddy, F. B., P. A. Kunzlik, and R. N. Bath. 1983. Uptake and loss of nitrite from the blood of rainbow trout, Salmo gairdneri Richardson, and atlantic salmon, Salmo salar L. in fresh water and in dilute sea water. Journal of Fish Biology 23:105-116.

FAO (Food and Agriculture Organization). 2002. State of the World Fisheries and Aquaculture Report. United Nations, FAO Information Division. Rome, Italy.

Fivelstad, S., H. Haavik, Geir Løvik, and A. B. Olsen. 1998. Sublethal effects and safe levels of carbon dioxide in seawater for Atlantic salmon postsmolts (Salmo salar L.): ion regulation and growth. Aquaculture 160:305-316.

Goss, G., P. Laurent, and S. Perry. 1994a. Gill morphology during hypercapnia in brown bullhead (Ictalurus nebulosus): role of chloride cells and pavement cells in acidbase regulation. Journal of Fish Biology 45: 705-718.

Goss, G., C. Wood, P. Laurent, and S. Perry. 1994b. Morphological responses of the rainbow trout (Oncorhynchus mykiss) gill to hyperoxia, base $\left(\mathrm{NaHCO}_{3}\right)$ and acid $(\mathrm{HCl})$ infusions. Fish Physiology and Biochemistry 12:465-477.

Hainly, R. A., and C. A. Looper. 1995. Water quality assessment of the lower 
Susquehanna River Basin, Pennsylvania and Maryland: sources, characteristics, analysis, and limitations of nutrient and suspended-sediment, 1975-1990. National Water-Quality Assessment Program, Report No. 97-4209. USGS, Leymone, Pennsylvania.

Hamilton, M. A., R. C. Russo, and R. V. Thurston. 1977. Trimmed Spearman-Karber method for estimating median lethal concentrations in toxicity bioassays. Environmental Science and Technology 11:714-718.

Houston, A. H. 1990. Blood and circulation. Pages 273-334 in C. B. Schreck and P. B. Moyle, editors. Methods for fish biology. American Fisheries Society, Bethesda, Maryland.

Iwama, G. K., and N. Heisler. 1991. Effect of environmental water salinity on acid-base regulation during environmental hypercapnia in the rainbow trout (Oncorhynchus mykiss). Journal of Experimental Biology 158:1-18.

Jenkins, M. R., and J. A. Hankins. 1996. West Virginia mine water inventory. Final report. The Conservation Fund's Freshwater Institute, Shepherdstown, West Virginia. 225 pp.

Jensen, F. B., P. Koldkjaer, and A. Bach. 2000. Anion uptake and acid-base and ionic effects during isolated and combined exposure to hypercapnia and nitrite in the freshwater crayfish, Astacus astacus. Journal of Comparative Physiology 170B:489-495.

Kozar. M. D., W. A. Hobba, Jr., and J. A. Macy. 1991. Geohydrology, water availability, and water quality of Jefferson County, West Virginia with emphasis on the carbonate area. Water-Resources Investigations Report 90-4118. USGS, Morgantown, West Virginia.

Mazik, P. M., M. L. Hinman, D. A. Winkelman, S. J. Klaine, B. A. Simco., and N. C. 
Parker. Influence of nitrite and chloride concentrations on survival and hematological profiles of striped bass. Transactions of the American Fisheries Society 120:247-254.

NASS (National Agricultural Statistical Service). 1998. Census of Aquaculture.

US Department of Agriculture. Charlestown, West Virginia.

Palacheck, R. M., and J. R. Tomasso. 1984. Toxicity of nitrite to channel catfish (Ictalurus punctatus), tilapia (Tilapia aurea), and largemouth bass (Micropterus salmoides): evidence for a nitrite exclusion mechanism. Canadian Journal of Fisheries and Aquatic Sciences 41:1739-1744.

Perrone, S. J., and T. L. Meade. 1977. Protective effect of chloride on nitrite toxicity to coho salmon (Oncorhynchus kisutch). Journal of the Fisheries Research Board of Canada $34: 486-492$.

Rodriguez-Moreno, P. A., and J. V. Tarazona. 1994. Nitrite-induced methemoglobin formation and recovery in rainbow trout (Oncorhynchus mykiss) at high chloride concentrations. Bulletin Environmental Contamination and Toxicology 53:113-119.

Russo, R. C., and R. V. Thurston. 1977. The acute toxicity of nitrite to fishes. Pages 118-131 in R. A. Tubbs, editor. Recent advances in fish toxicology. U.S. Environmental Protection Agency, EPA Ecological Research Service, EPA-600/3-77-085, Corvallis, Oregon.

Russo, R. C., R. V. Thurston, and K. Emerson. 1981. Acute toxicity of nitrite to rainbow trout (Salmo gairdneri): effects of $\mathrm{pH}$, nitrite species, and anion species. Canadian Journal of Fisheries and Aquatic Sciences 38:387-393.

Scarano, G., and M. G. Saroglia. 1984. Recovery of fish from functional and haemolytic anaemia after brief exposure to a lethal concentration of nitrite. Aquaculture 43:421-426. 
Smart, G. R. 1981. Aspects of water quality producing stress in intensive fish culture. Pages 277-293 in A. D. Pickering, editor. Stress and fish. Academic Press, New York. Summerfelt, S. T. 2001. Carbon dioxide. Pages 141-147 in R. R. Stickney, editor. Encyclopedia of Aquaculture. John Wiley \& Sons, Inc., New York, New York. Summerfelt, S. T., B. J. Vinci, and R. H. Piedrahita. 2000. Oxygenation and carbon dioxide control in water reuse systems. Aquacultural Engineering 22:87-108.

Thomas, P. M., N. W. Pankhurst, and H. A. Bremner. 1999. The effect of stress and exercise on post-mortem biochemistry of Atlantic salmon and rainbow trout. Journal of Fish Biology 54:1177-1196.

Timmons, M. B., J. M. Ebeling, F. W. Wheaton, S. T. Summerfelt, and B. J. Vinci. 2001. Recirculating Aquaculture Systems. Northeast Regional Aquaculture Center. Publication No. 01-002. Cayuga Aqua Ventures, Ithica, New York.

Tomasso, J. R. 1986. Comparative toxicity of nitrite to freshwater fishes. Aquatic Toxicology 8:129-137.

Tomasso, J. R. 1994. Toxicity of nitrogenous wastes to aquaculture animals. Review in Fisheries Science 2:291-313.

Tomasso, J. R., B. A. Simco, and K. B. Davis. 1979. Chloride inhibition of nitriteinduced methemoglobinemia in channel catfish (Ictalurus punctatus). Journal of Fisheries Research Board of Canada 36:1141-1144.

USEPA (U.S. Environmental Protection Agency). 1974. Methods for chemical analysis of water and wastes. U.S. Environmental Protection Agency, EPA-625/6-74-003, Washington, D.C.

Vanderpool, A., D’Souza, G., McCauley, A., Gempesaw II, C., and Bacon, J. R. 1993. 
The potential of aquaculture production in West Virginia: a survey of current and potential aquaculture producers. Project report. The Conservation Fund's Freshwater Institute, Shepherdstown, WV.

Vedel, N. E., B. Korsgaard, and F. B. Jensen. 1998. Isolated and combined exposure to ammonia and nitrite in rainbow trout (Oncorhynchus mykiss): effects on electrolyte status, blood respiratory properties and brain glutamine/glutamate concentrations. Aquatic Toxicology 41:325-342.

WVBEP (West Virginia Bureau of Employment Programs). 2003. West Virginia Labor Force Statistics July, 2003. State of West Virginia, Bureau of Employment Programs. Charleston, West Virginia.

Wedemeyer, G. A. 1996. Interactions with water quality conditions: carbon dioxide. Pages 67-69 in G. A. Wedemeyer, editor. Physiology of fish in intensive culture systems. Chapman and Hall, New York.

Wedemeyer, G. A., and W. T. Yasutake. 1978. Prevention and treatment of nitrite toxicity in juvenile steelhead trout (Salmo gairdneri). Journal of the Fisheries Research Board of Canada 35:822-827.

Williams, E. M., and F. B. Eddy. 1988. Regulation of blood haemoglobin and electrolytes in rainbow trout Salmo gairdneri (Richardson) exposed to nitrite. Aquatic Toxicology 13:13-28.

Wurts, W. A., and R. M. Durborow. 1992. Interactions of pH, carbon dioxide, alkalinity and hardness in fish ponds. Southern Regional Aquaculture Center. No. 464. Retrieved November 7, 2002, from http://www.msstate.edu/dept/srac/fslist.htm. 
Table 1. Blood and plasma parameters (mean \pm SEM) of rainbow trout (Oncorhynchus mykiss) from experiment 1. Same lower case letters indicate no significant difference

\begin{tabular}{ccccc}
\hline $\begin{array}{c}\text { Environmental } \\
(\mathrm{mg} / \mathrm{L} \text { nitrite-N) }\end{array}$ & $\mathrm{n}$ & Hematocrit $(\%)$ & $\begin{array}{c}\text { Plasma Glucose } \\
(\mathrm{mg} / \mathrm{dL})\end{array}$ & $\begin{array}{c}\text { Plasma Lactate } \\
(\mathrm{mg} / \mathrm{dL})\end{array}$ \\
\hline 0.4 & 15 & $42.8 \pm 1.7 \mathrm{a}$ & $80.4 \pm 16.7 \mathrm{ab}$ & $28.2 \pm 2.5 \mathrm{a}$ \\
3.6 & 15 & $35.0 \pm 1.6 \mathrm{ab}$ & $70.5 \pm 8.2 \mathrm{~b}$ & $38.0 \pm 4.7 \mathrm{a}$ \\
7.1 & 11 & $31.6 \pm 1.4 \mathrm{~b}$ & $66.0 \pm 4.8 \mathrm{~b}$ & $76.8 \pm 21.5 \mathrm{a}$ \\
13.2 & 1 & $34.0 \pm 0 \mathrm{ab}$ & $117.0 \pm 0 \mathrm{a}$ & $74.0 \pm 0 \mathrm{a}$ \\
20.9 & 2 & $31.4 \pm 2.5 \mathrm{~b}$ & $83.3 \pm 6.3 \mathrm{~b}$ & $72.0 \pm 36.5 \mathrm{a}$ \\
\hline
\end{tabular}


Table 2. Blood and plasma parameters (mean \pm SEM) of rainbow trout (Oncorhynchus mykiss) from experiment 2. Same lower case letters indicate no significant difference

\begin{tabular}{cccccc}
\hline $\begin{array}{c}\text { Environmental } \\
(\mathrm{mg} / \mathrm{L} \text { nitrite-N) }\end{array}$ & $\mathrm{n}$ & $\begin{array}{c}\text { Hematocrit } \\
(\%)\end{array}$ & $\begin{array}{c}\text { Plasma Glucose } \\
(\mathrm{mg} / \mathrm{dL})\end{array}$ & $\begin{array}{c}\text { Plasma Lactate } \\
(\mathrm{mg} / \mathrm{dL})\end{array}$ & $\begin{array}{c}\text { Plasma Chloride } \\
(\mathrm{mEq} / \mathrm{L})\end{array}$ \\
\hline 0.5 & 15 & $42.5 \pm 1.5 \mathrm{a}$ & $62.8 \pm 1.8 \mathrm{a}$ & $26.0 \pm 1.4 \mathrm{ab}$ & $126.0 \pm 1.8 \mathrm{a}$ \\
1.4 & 15 & $44.1 \pm 1.5 \mathrm{a}$ & $58.7 \pm 2.1 \mathrm{a}$ & $23.0 \pm 1.3 \mathrm{ab}$ & $119.4 \pm 1.9 \mathrm{a}$ \\
1.6 & 15 & $38.4 \pm 1.5 \mathrm{a}$ & $55.7 \pm 3.9 \mathrm{a}$ & $17.8 \pm 2.0 \mathrm{~b}$ & $124.8 \pm 1.6 \mathrm{a}$ \\
2.1 & 13 & $38.5 \pm 1.6 \mathrm{a}$ & $41.1 \pm 3.0 \mathrm{ab}$ & $20.9 \pm 1.9 \mathrm{~b}$ & $116.4 \pm 2.5 \mathrm{a}$ \\
3.2 & 6 & $41.5 \pm 4.6 \mathrm{a}$ & $69.2 \pm 8.0 \mathrm{a}$ & $29.7 \pm 4.9 \mathrm{ab}$ & $115.9 \pm 10.0 \mathrm{a}$ \\
4.7 & 2 & $40.1 \pm 0.9 \mathrm{a}$ & $56.3 \pm 0.1 \mathrm{a}$ & $40.4 \pm 18.6 \mathrm{a}$ & $123.5 \pm 10.0 \mathrm{a}$ \\
\hline
\end{tabular}


Table 3. Blood and plasma parameters (mean \pm SEM) of rainbow trout (Oncorhynchus mykiss) from experiment 3. Same lower case letters indicate no significant difference

\begin{tabular}{ccccc}
\hline $\begin{array}{c}\text { Environmental } \\
(\mathrm{mg} / \mathrm{L} \mathrm{NaCl})\end{array}$ & $\mathrm{n}$ & Hematocrit $(\%)$ & $\begin{array}{c}\text { Plasma Glucose } \\
(\mathrm{mg} / \mathrm{dL})\end{array}$ & $\begin{array}{c}\text { Plasma Chloride } \\
(\mathrm{mEq} / \mathrm{L})\end{array}$ \\
\hline 28.3 & 1 & $35.0 \pm 0 \mathrm{a}$ & $71.9 \pm 0 \mathrm{a}$ & $120.5 \pm 0 \mathrm{a}$ \\
35.7 & 5 & $34.7 \pm 2.8 \mathrm{a}$ & $45.1 \pm 5.8 \mathrm{~b}$ & $114.4 \pm 2.2 \mathrm{a}$ \\
48.0 & 11 & $36.8 \pm 1.1 \mathrm{a}$ & $50.9 \pm 2.9 \mathrm{~b}$ & $121.5 \pm 2.3 \mathrm{a}$ \\
67.5 & 14 & $37.7 \pm 1.5 \mathrm{a}$ & $57.3 \pm 3.4 \mathrm{ab}$ & $117.0 \pm 1.8 \mathrm{a}$ \\
100.0 & 13 & $41.5 \pm 1.6 \mathrm{a}$ & $54.0 \pm 3.2 \mathrm{~b}$ & $122.6 \pm 2.2 \mathrm{a}$ \\
165.2 & 15 & $39.8 \pm 1.4 \mathrm{a}$ & $49.9 \pm 1.9 \mathrm{~b}$ & $124.2 \pm 1.5 \mathrm{a}$ \\
\hline
\end{tabular}


Table 4. Blood and plasma parameters (mean \pm SEM) of rainbow trout (Oncorhynchus mykiss) from experiment 4. Same lower case letters indicate no significant difference.

\begin{tabular}{cccccccc}
\hline $\begin{array}{c}\text { Environmental } \\
(\mathrm{mg} / \mathrm{L} \text { nitrite-N })\end{array}$ & $\begin{array}{c}\text { Environmental } \\
(\mathrm{mg} / \mathrm{L} \mathrm{CO})\end{array}$ & $\mathrm{n}$ & Hematocrit $(\%)$ & $\begin{array}{c}\text { Plasma Nitrite } \\
(\mathrm{mg} / \mathrm{L} \text { nitrite- } \\
\mathrm{N})\end{array}$ & $\begin{array}{c}\text { Plasma } \\
\text { Glucose } \\
(\mathrm{mg} / \mathrm{dL})\end{array}$ & $\begin{array}{c}\text { Plasma } \\
\text { Lactate } \\
(\mathrm{mg} / \mathrm{dL})\end{array}$ & $\begin{array}{c}\text { Plasma } \\
\text { Chloride } \\
(\mathrm{mEq} / \mathrm{L})\end{array}$ \\
\hline $0.08 \pm 0.02$ & $9.1 \pm 0.5$ & 10 & $37.6 \pm 1.9 \mathrm{a}$ & $0.24 \pm 0.02 \mathrm{a}$ & $62.6 \pm 1.7 \mathrm{a}$ & $21.0 \pm 1.5 \mathrm{a}$ & $109.9 \pm 1.8 \mathrm{a}$ \\
$0.8 \pm 0.03$ & $9.0 \pm 0.3$ & 9 & $34.1 \pm 1.3 \mathrm{a}$ & $5.6 \pm 1.7 \mathrm{a}$ & $61.5 \pm 5.7 \mathrm{a}$ & $21.8 \pm 1.1 \mathrm{a}$ & $107.0 \pm 1.9 \mathrm{a}$ \\
$0.8 \pm 0.03$ & $13.8 \pm 0.8$ & 9 & $28.0 \pm 2.0 \mathrm{a}$ & $22.4 \pm 4.0 \mathrm{a}$ & $44.8 \pm 3.7 \mathrm{a}$ & $16.5 \pm 2.1 \mathrm{a}$ & $104.4 \pm 1.3 \mathrm{a}$ \\
$0.8 \pm 0.03$ & $23.4 \pm 1.0$ & 7 & $30.1 \pm 2.1 \mathrm{a}$ & $14.9 \pm 3.4 \mathrm{a}$ & $45.3 \pm 4.8 \mathrm{a}$ & $12.2 \pm 1.0 \mathrm{a}$ & $93.2 \pm 3.4 \mathrm{a}$ \\
$2.1 \pm 0.03$ & $9.0 \pm 0.3$ & 6 & $27.9 \pm 1.2 \mathrm{a}$ & $24.7 \pm 8.4 \mathrm{a}$ & $51.9 \pm 10.0 \mathrm{a}$ & $18.1 \pm 3.6 \mathrm{a}$ & $101.2 \pm 4.1 \mathrm{a}$ \\
$2.1 \pm 0.03$ & $13.8 \pm 0.8$ & 3 & $37.1 \pm 5.8 \mathrm{a}$ & $8.3 \pm 5.3 \mathrm{a}$ & $77.1 \pm 9.5 \mathrm{a}$ & $21.9 \pm 5.5 \mathrm{a}$ & $97.8 \pm 3.6 \mathrm{a}$ \\
$2.1 \pm 0.03$ & $23.4 \pm 1.0$ & 6 & $31.5 \pm 1.1 \mathrm{a}$ & $14.9 \pm 9.0 \mathrm{a}$ & $56.5 \pm 3.5 \mathrm{a}$ & $24.1 \pm 4.7 \mathrm{a}$ & $100.8 \pm 1.5 \mathrm{a}$ \\
\hline
\end{tabular}


Table 5. Blood and plasma parameters (mean \pm SEM) of rainbow trout (Oncorhynchus mykiss) from experiment 5. Same lower case letters indicate no significant difference.

\begin{tabular}{ccccccc}
\hline $\begin{array}{c}\text { Environmental } \\
(\mathrm{mg} / \mathrm{L} \text { nitrite-N) }\end{array}$ & $\begin{array}{c}\text { Environmental } \\
(\mathrm{mg} / \mathrm{L} \mathrm{CO})\end{array}$ & $\mathrm{n}$ & $\begin{array}{c}\text { Hematocrit } \\
(\%)\end{array}$ & $\begin{array}{c}\text { Plasma Glucose } \\
(\mathrm{mg} / \mathrm{dL})\end{array}$ & $\begin{array}{c}\text { Plasma Lactate } \\
(\mathrm{mg} / \mathrm{dL})\end{array}$ & $\begin{array}{c}\text { Plasma Chloride } \\
(\mathrm{mEq} / \mathrm{L})\end{array}$ \\
\hline $0.1 \pm 0.04$ & $8.3 \pm 0.7$ & 10 & $43.4 \pm 1.7 \mathrm{a}$ & $116.9 \pm 18.5 \mathrm{a}$ & $36.3 \pm 8.8 \mathrm{a}$ & $102.5 \pm 2.5 \mathrm{a}$ \\
$9.6 \pm 0.06$ & $7.7 \pm 0.4$ & 5 & $32.1 \pm 1.4 \mathrm{a}$ & $59.5 \pm 15.8 \mathrm{~b}$ & $25.5 \pm 8.8 \mathrm{a}$ & $100.0 \pm 3.0 \mathrm{a}$ \\
$9.6 \pm 0.06$ & $14.8 \pm 0.7$ & 4 & $30.2 \pm 3.5 \mathrm{a}$ & $67.7 \pm 8.7 \mathrm{~b}$ & $16.1 \pm 4.9 \mathrm{a}$ & $102.9 \pm 3.6 \mathrm{a}$ \\
$9.6 \pm 0.06$ & $29.7 \pm 1.9$ & 2 & $29.9 \pm 0.4 \mathrm{a}$ & $50.7 \pm 3.4 \mathrm{~b}$ & $20.7 \pm 8.1 \mathrm{a}$ & $95.8 \pm 3.3 \mathrm{a}$ \\
$9.6 \pm 0.06$ & $7.7 \pm 0.4$ & 10 & $38.4 \pm 2.2 \mathrm{a}$ & $62.8 \pm 6.5 \mathrm{~b}$ & $31.6 \pm 9.5 \mathrm{a}$ & $115.5 \pm 2.7 \mathrm{a}$ \\
$9.6 \pm 0.06$ & $14.8 \pm 0.7$ & 8 & $33.7 \pm 3.6 \mathrm{a}$ & $49.0 \pm 2.8 \mathrm{~b}$ & $10.5 \pm 1.4 \mathrm{a}$ & $109.5 \pm 1.5 \mathrm{a}$ \\
$9.6 \pm 0.06$ & $29.7 \pm 1.9$ & 10 & $36.0 \pm 1.6 \mathrm{a}$ & $50.6 \pm 3 . \mathrm{b}$ & $13.8 \pm 1.5 \mathrm{a}$ & $88.3 \pm 1.6 \mathrm{a}$ \\
\hline
\end{tabular}


Figure 1. Percent mortality of rainbow trout exposed for $24 \mathrm{~h}$ to environmental nitrite-N

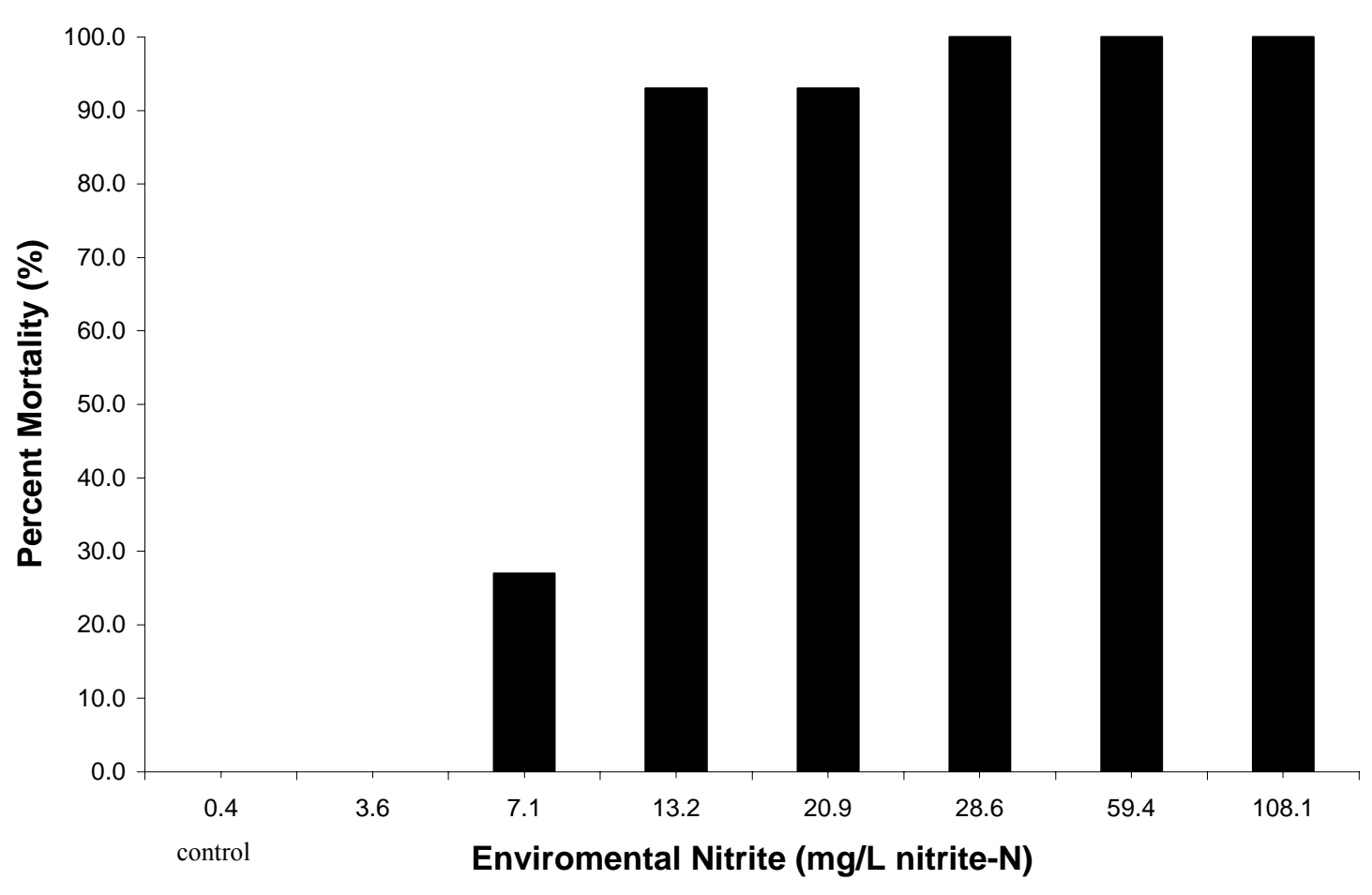


Figure 2. Plasma nitrite (mean $\pm \mathrm{SEM}$ ) in rainbow trout exposed for $24 \mathrm{~h}$ to increasing concentrations of environmental nitrite-N

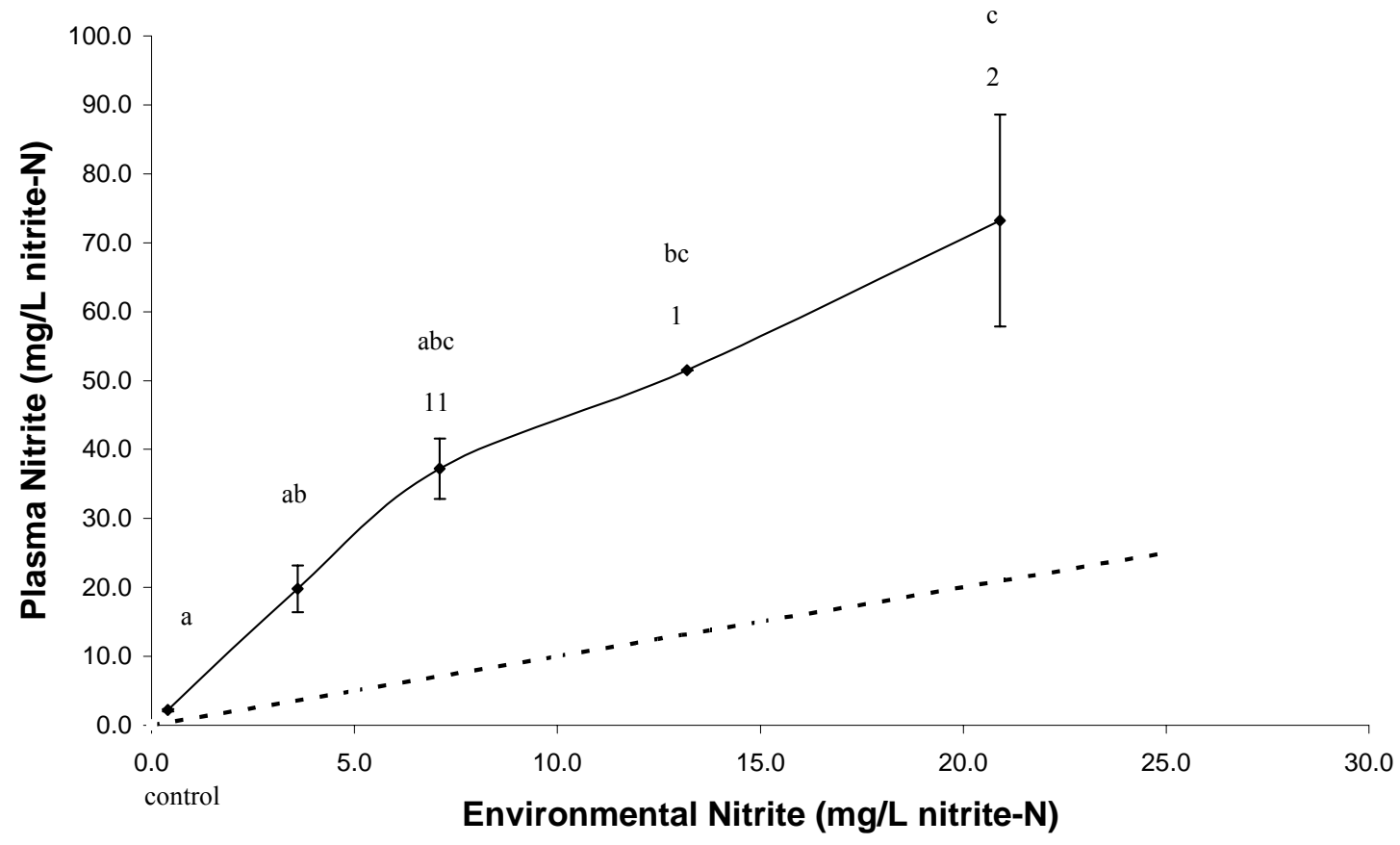


Figure 3. Plasma chloride (mean \pm SEM) in rainbow trout exposed for $24 \mathrm{~h}$ to increasing concentrations of environmental nitrite-N

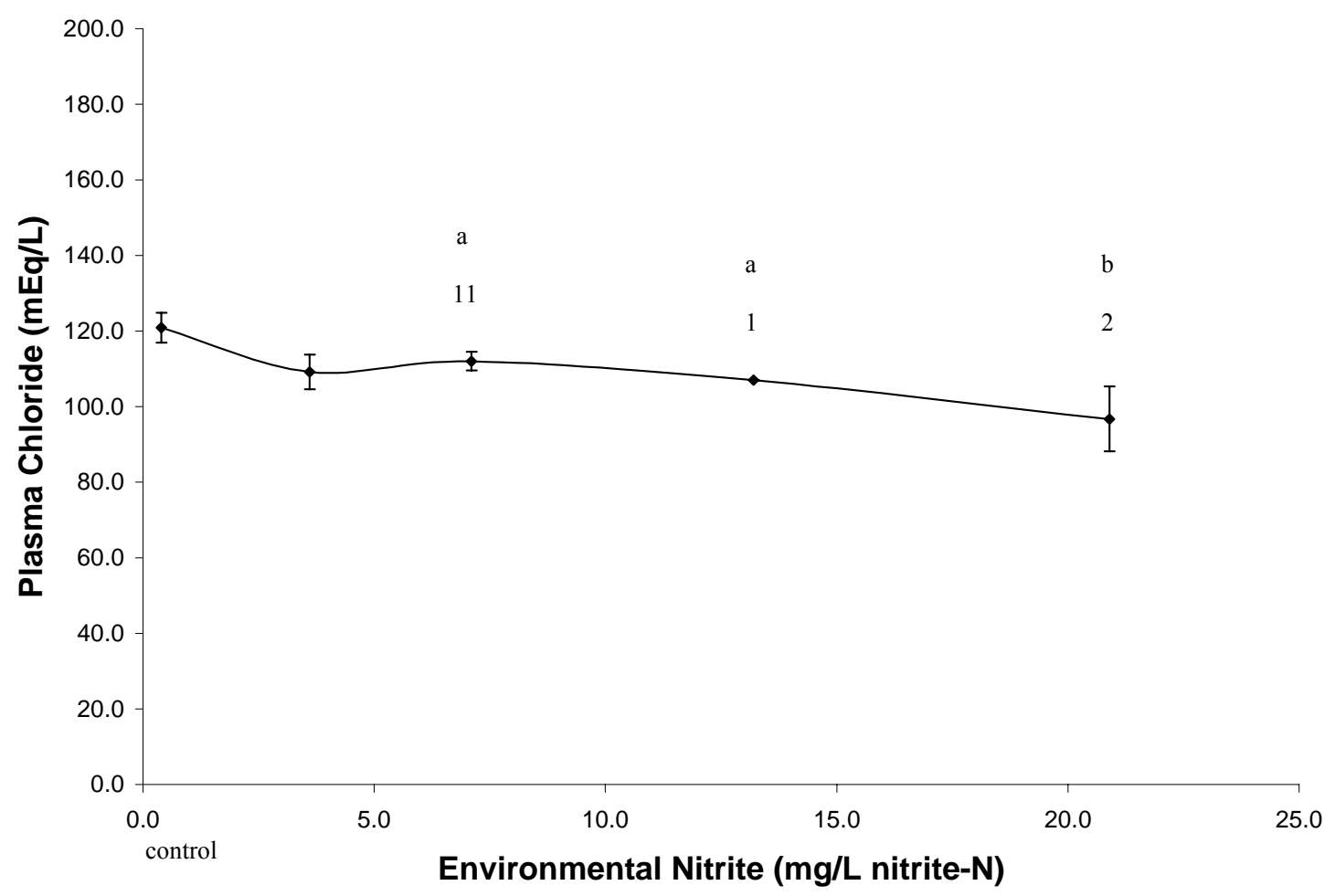


Figure 4. Percent mortality of rainbow trout exposed for $96 \mathrm{~h}$ to environmental nitrite-N

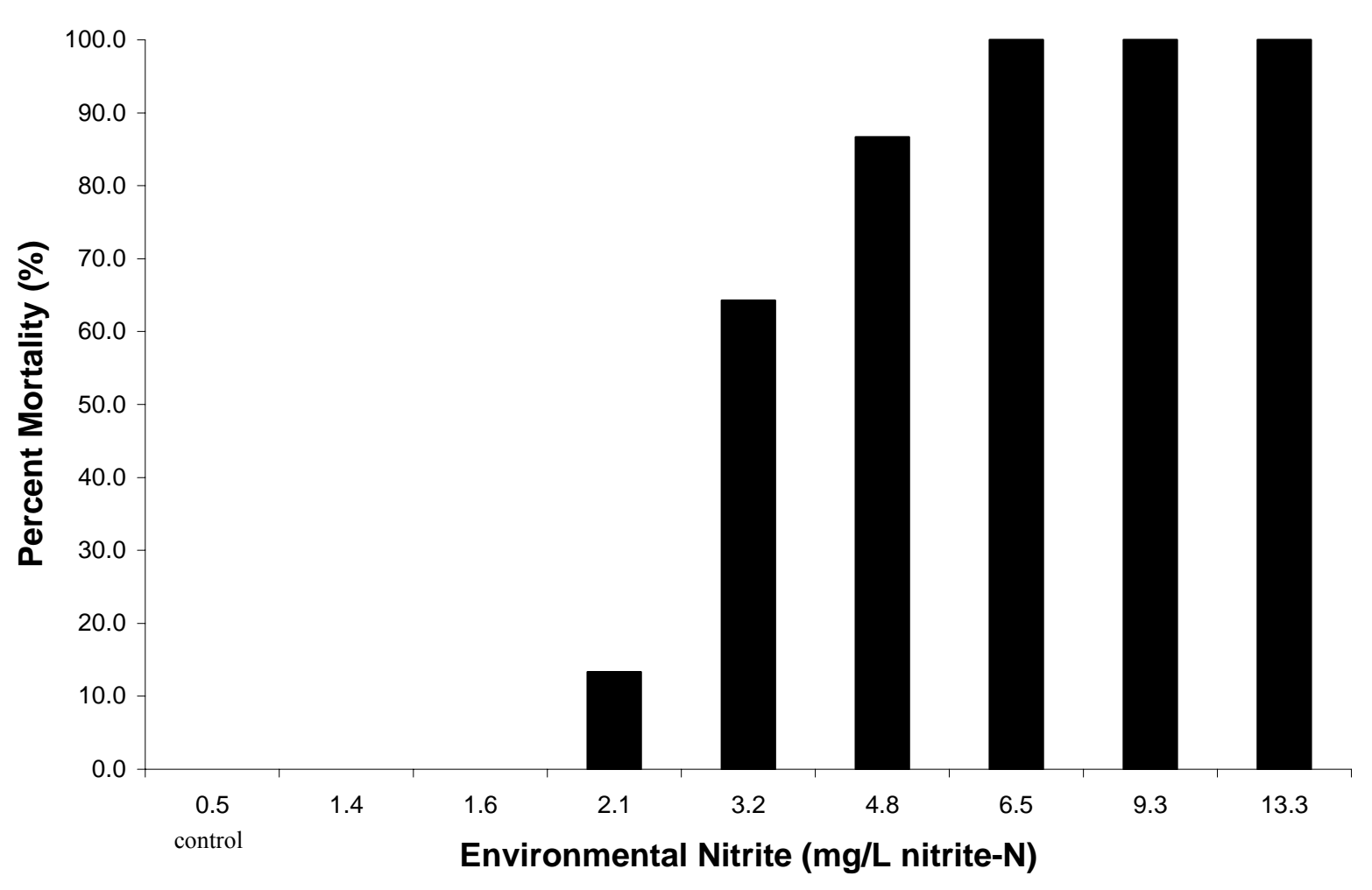


Figure 5. Plasma nitrite (mean $\pm \mathrm{SEM}$ ) in rainbow trout exposed for $96 \mathrm{~h}$ to increasing concentrations of environmental nitrite-N

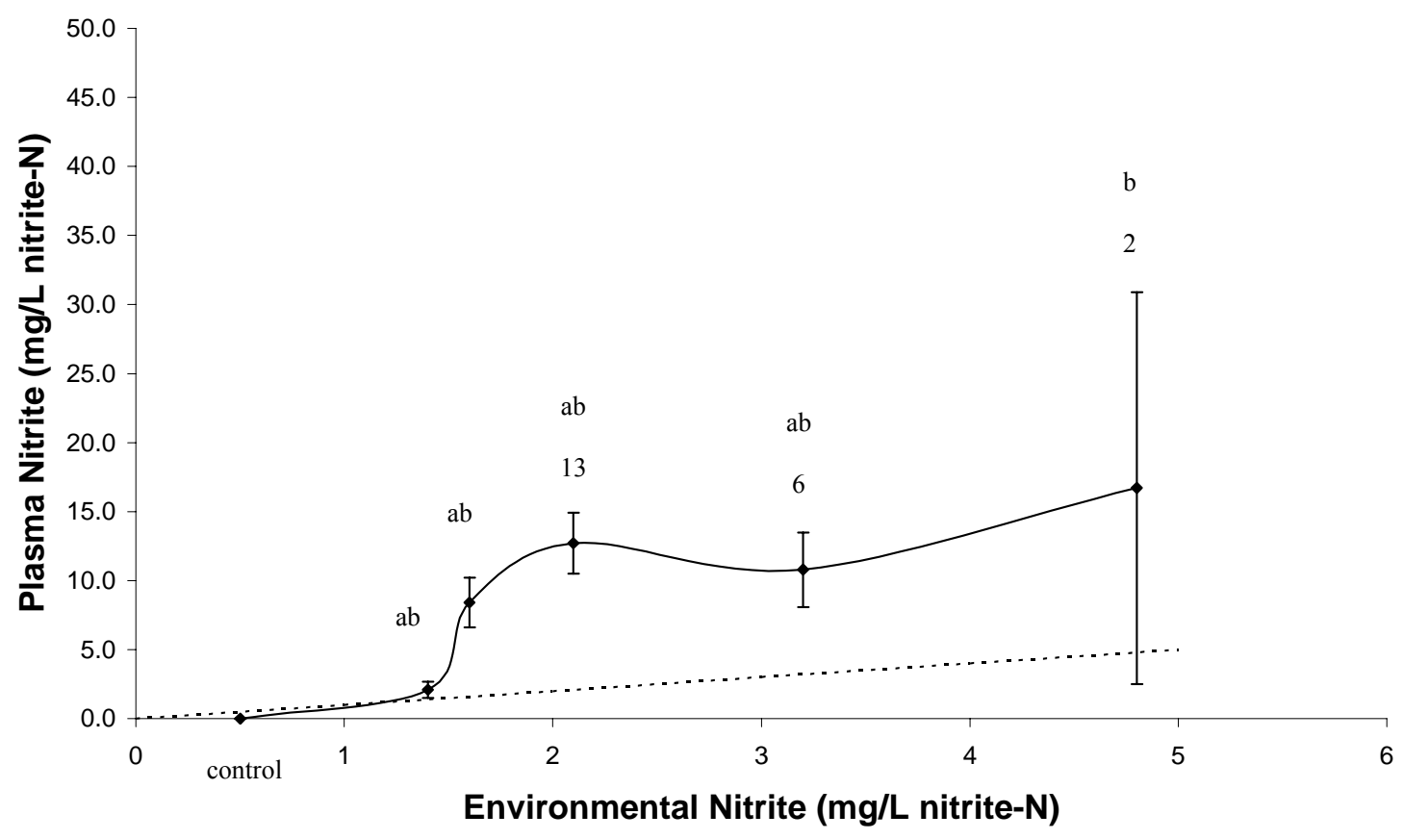


Figure 6. Percent survival of rainbow trout exposed for $96 \mathrm{~h}$ to a lethal level of nitrite-N to increasing concentrations of environmental chloride

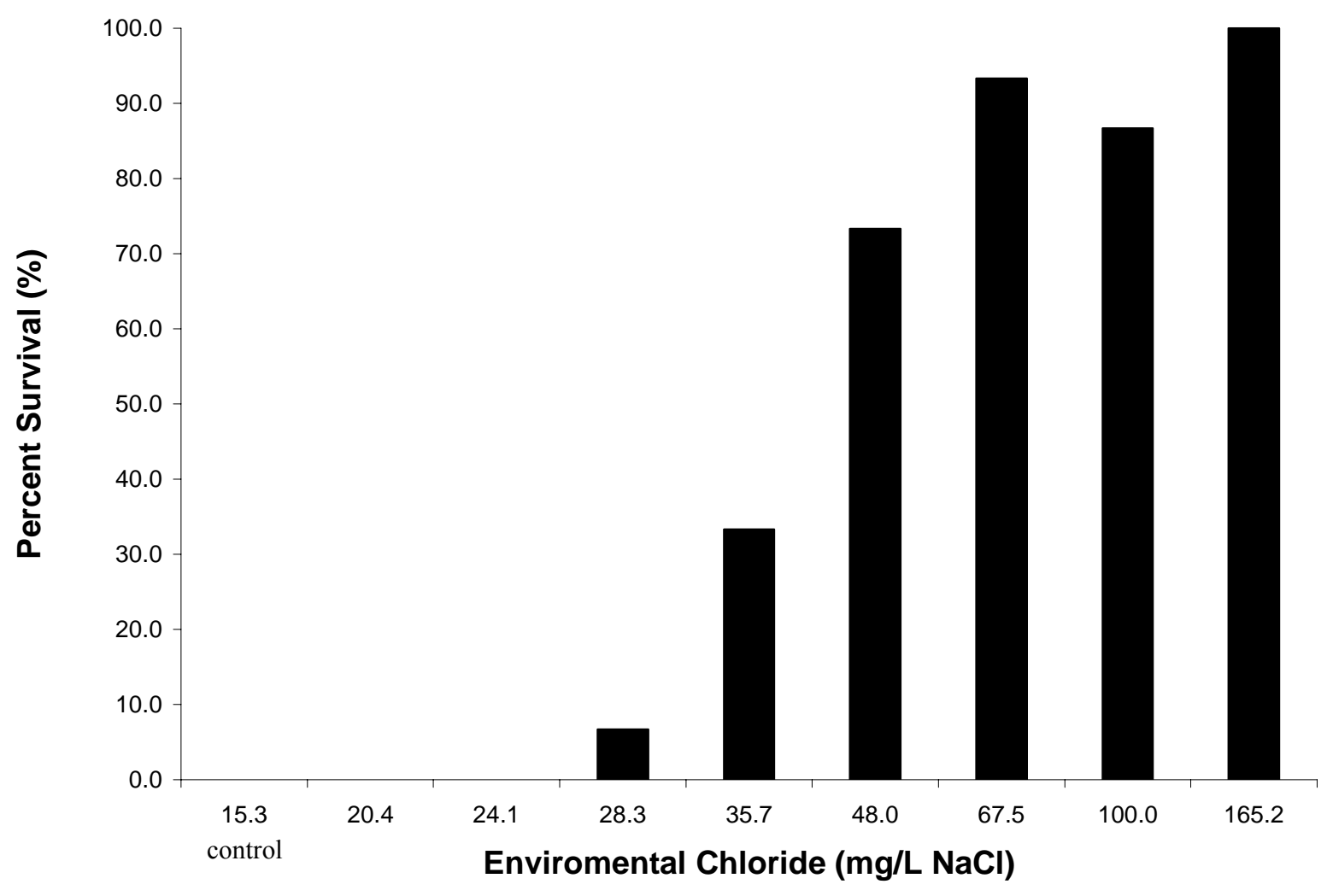


Figure 7. Plasma nitrite (mean $\pm \mathrm{SEM}$ ) in rainbow trout exposed for $96 \mathrm{~h}$ to a lethal level of nitrite- $\mathrm{N}$ in increasing concentrations of environmental chloride

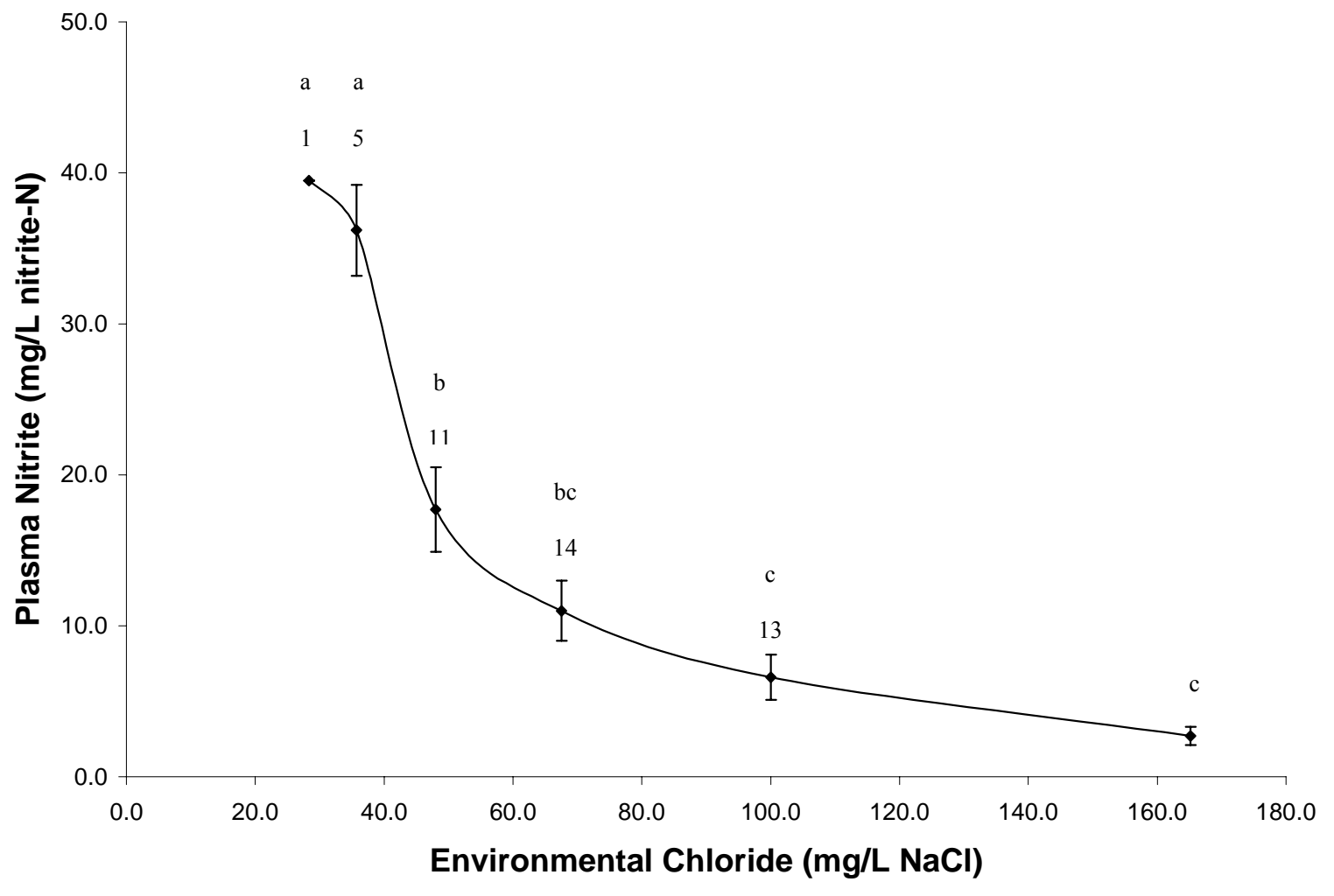


Figure 8. Plasma lactate (mean $\pm \mathrm{SEM}$ ) in rainbow trout exposed for $96 \mathrm{~h}$ to a lethal level of nitrite- $\mathrm{N}$ in increasing concentrations of environmental chloride

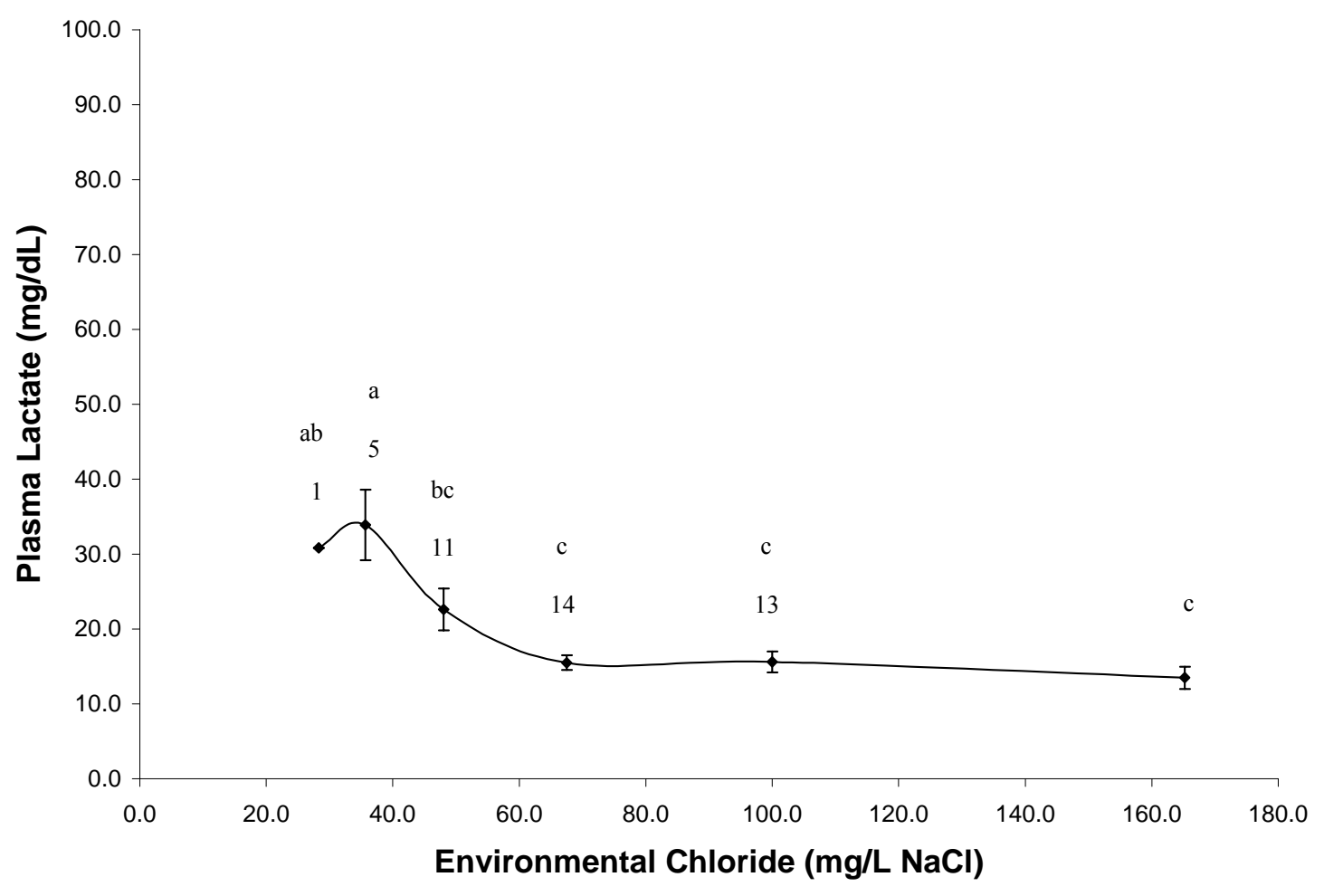


Figure 9. Percent mortality of rainbow trout exposed for $96 \mathrm{~h}$ to increasing concentrations of environmental nitrite- $\mathrm{N}$ and carbon dioxide

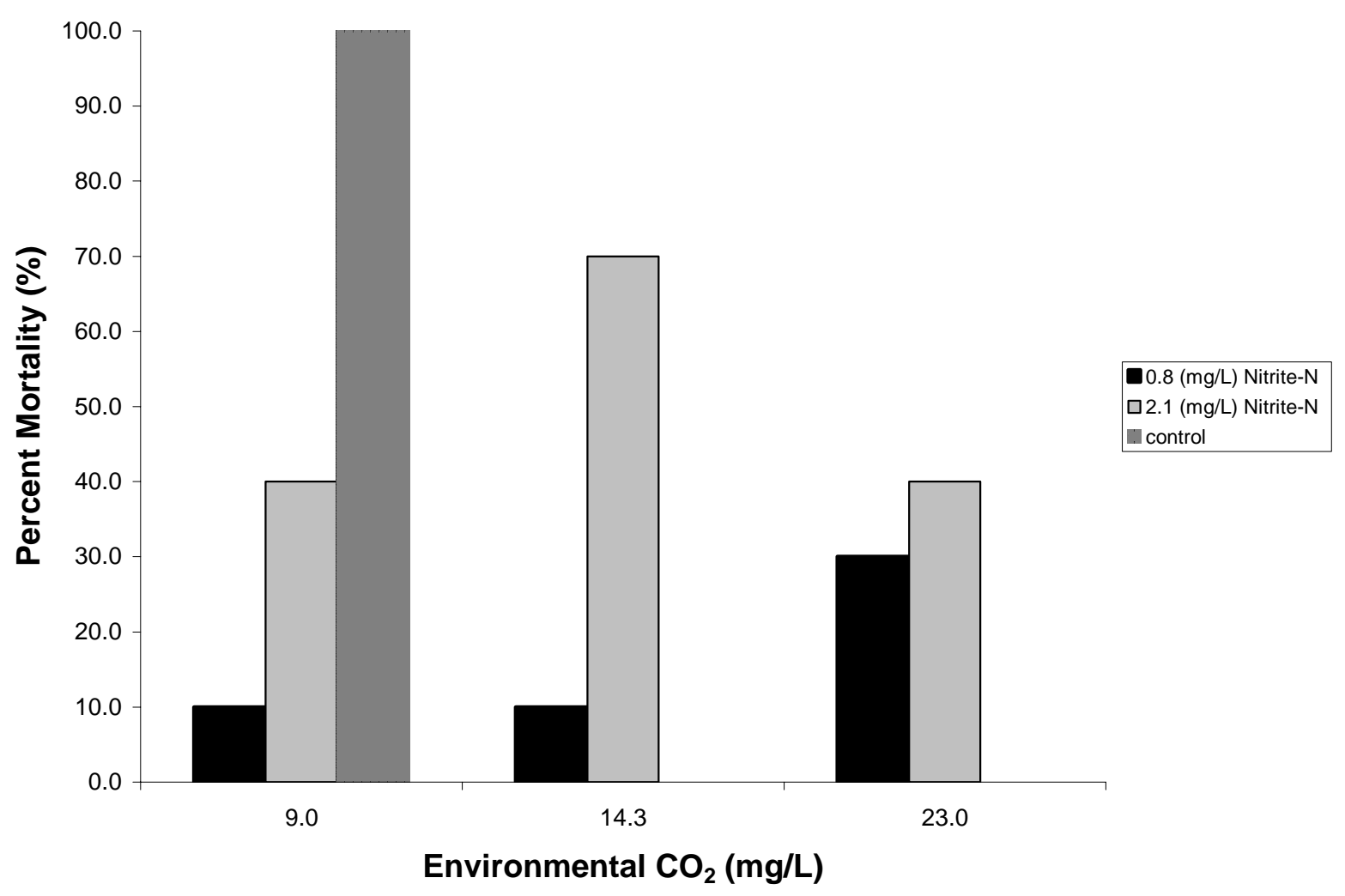


Figure 10. Percent survival of rainbow trout exposed for $96 \mathrm{~h}$ to a lethal level of nitrite-N to increasing concentrations of environmental chloride and carbon dioxide

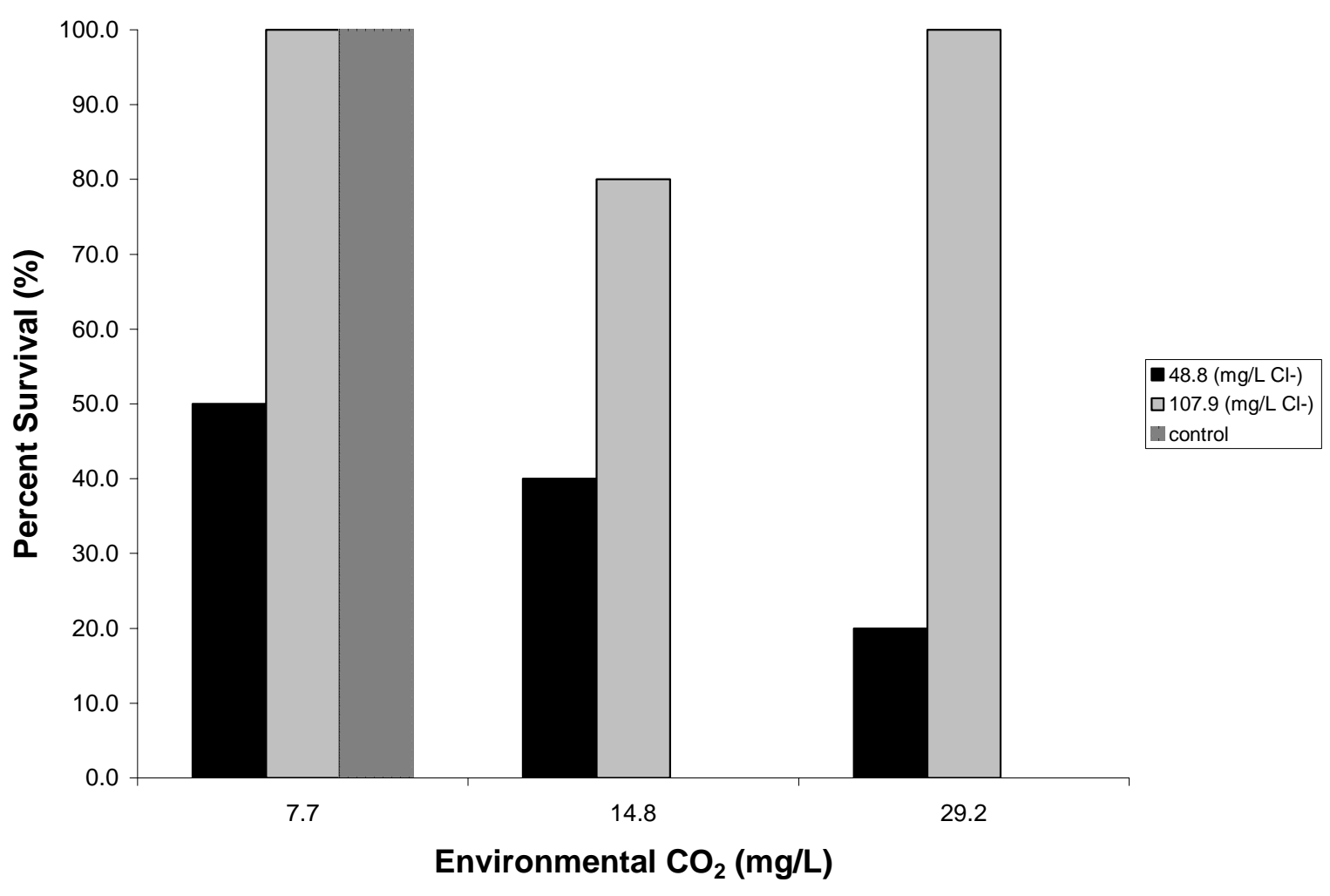


Figure 11. Plasma nitrite (mean $\pm \mathrm{SEM}$ ) in rainbow trout exposed for $96 \mathrm{~h}$ to a lethal of nitrite-N in increasing concentrations of environmental chloride and carbon dioxide

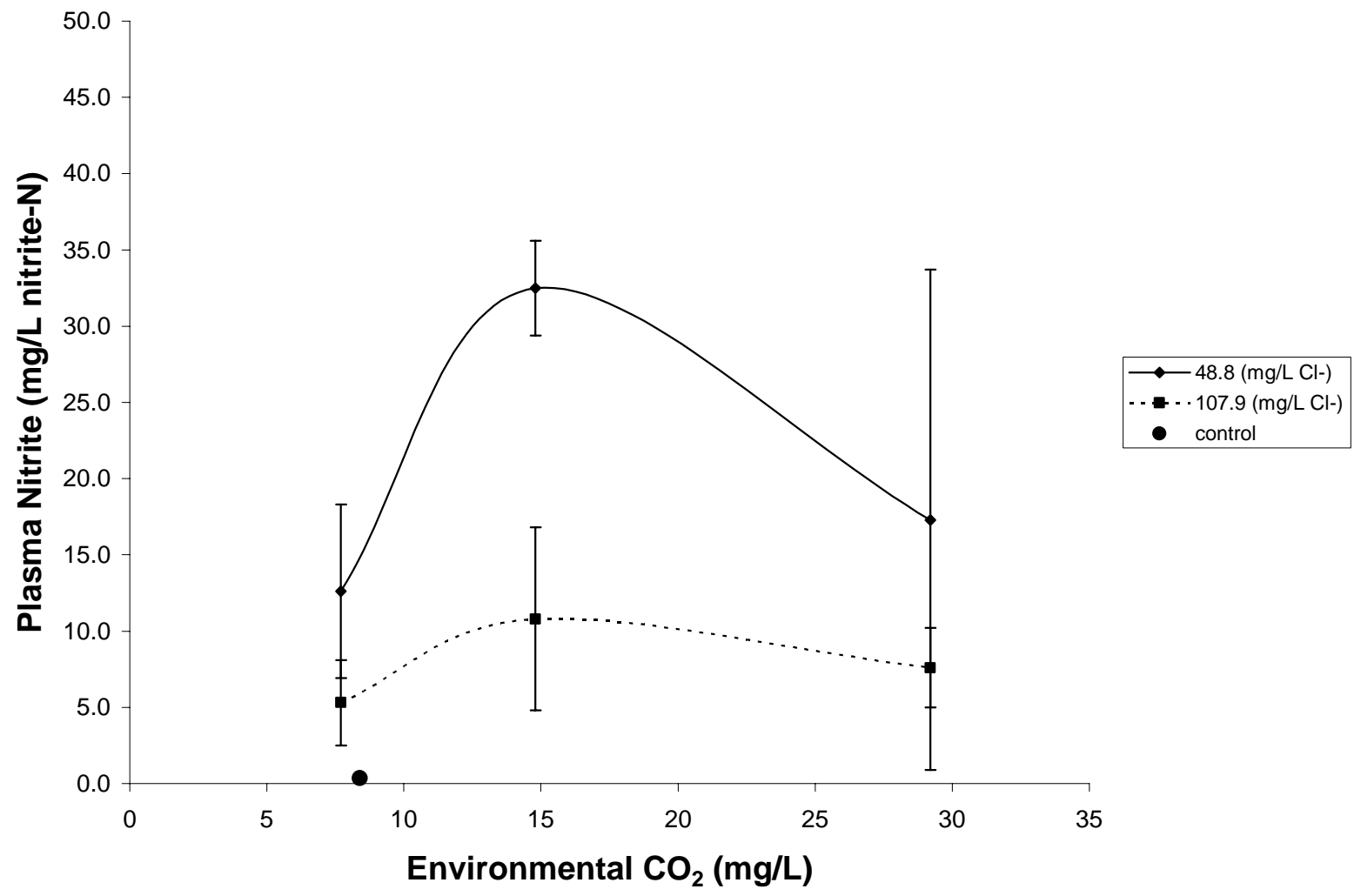


Figure 12. Plasma chloride (mean $\pm \mathrm{SEM}$ ) in rainbow trout exposed for $96 \mathrm{~h}$ to a lethal of nitrite- $\mathrm{N}$ in increasing concentrations of environmental chloride and carbon dioxide

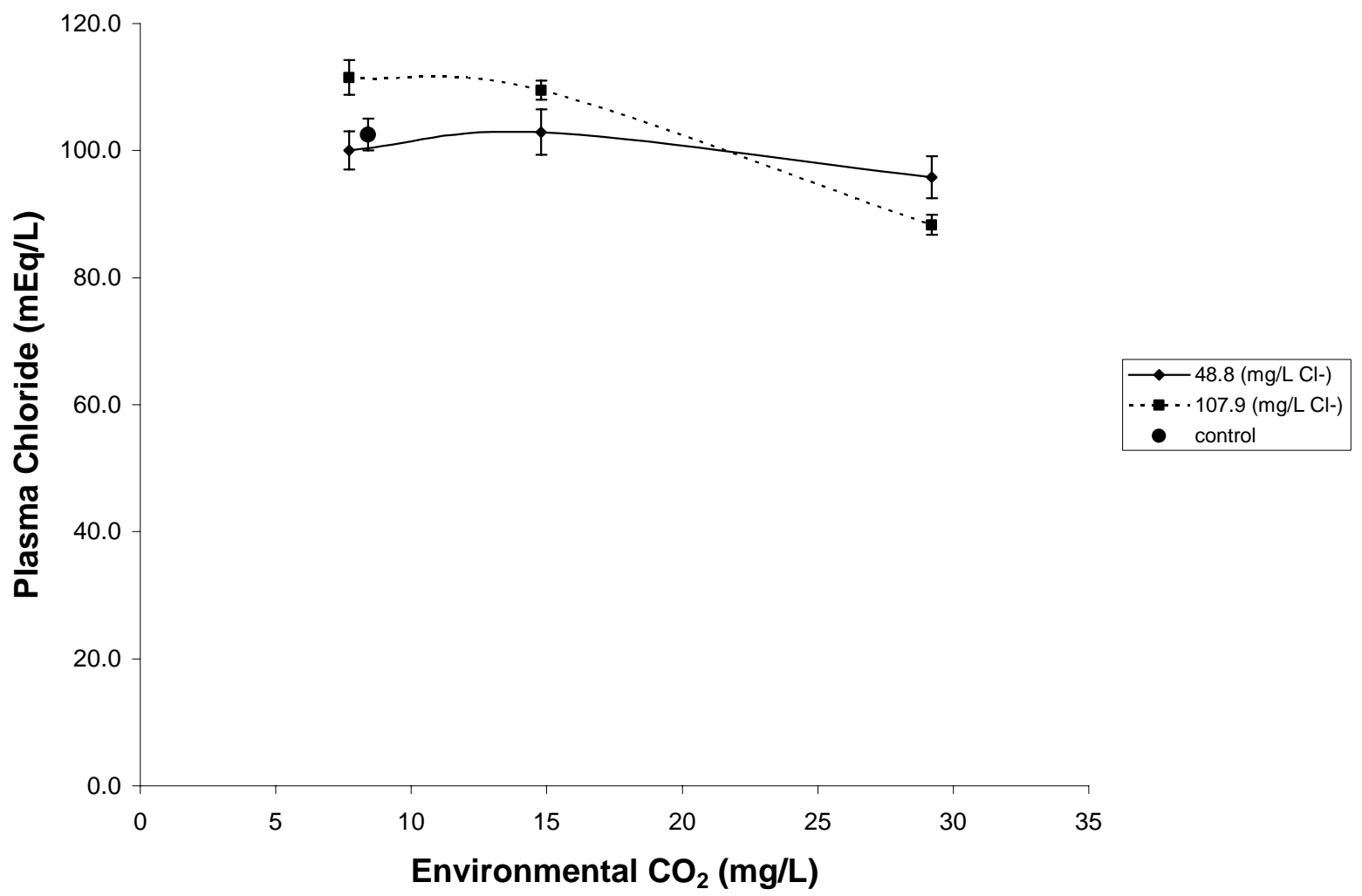


Appendix A. Mean \pm SEM of water quality values from experiments one through five.

\begin{tabular}{cccccccc}
\hline Experiment & $\begin{array}{c}\text { Temperature } \\
\left({ }^{\circ} \mathrm{C}\right)\end{array}$ & $\begin{array}{c}\text { Dissolved } \\
\text { oxygen } \\
(\mathrm{mg} / \mathrm{L})\end{array}$ & $\mathrm{pH}$ & $\mathrm{TAN}(\mathrm{mg} / \mathrm{L})$ & $\begin{array}{c}\text { Alkalinity } \\
(\mathrm{mg} / \mathrm{L})\end{array}$ & $\begin{array}{c}\mathrm{Ca}++ \\
\text { Hardness } \\
(\mathrm{mg} / \mathrm{L})\end{array}$ & $\begin{array}{c}\text { Carbon } \\
\text { dioxide } \\
(\mathrm{mg} / \mathrm{L})\end{array}$ \\
\hline 1 & $13.7 \pm 0.4$ & $8.75 \pm 1.0$ & $8.05 \pm 0.13$ & $1.8 \pm 0.5$ & $234.0 \pm 1.4$ & $238.0 \pm 1.4$ & $13.0 \pm 1.4$ \\
2 & $13.7 \pm 0.3$ & $9.43 \pm 0.7$ & $8.12 \pm 0.13$ & $1.2 \pm 0.4$ & $250.0 \pm 2.8$ & $234.0 \pm 2.1$ & $11.5 \pm 2.1$ \\
3 & $14.6 \pm 0.1$ & $8.99 \pm 0.1$ & $8.09 \pm 0.01$ & $0.8 \pm 0.1$ & $241.0 \pm 1.0$ & $244.0 \pm 1.5$ & $10.5 \pm 0.5$ \\
4 & $14.0 \pm 0.01$ & $12.13 \pm 0.2$ & $7.82 \pm 0.01$ & $0.02 \pm 0.002$ & $201.0 \pm 2.3$ & $230.0 \pm 5.2$ & $9.0 \pm 0.3$ \\
& & & $7.65 \pm 0.01$ & & & & $14.3 \pm 0.8$ \\
5 & $14.06 \pm 0.01$ & $12.54 \pm 0.2$ & $7.42 \pm 0.03$ & & & & $22.9 \pm 1.3$ \\
& & & $7.60 \pm 0.02$ & $0.04 \pm 0.004$ & $256.0 \pm 26.1$ & $240.0 \pm 7.2$ & $7.7 \pm 0.4$ \\
& & & $7.31 \pm 0.04$ & & & & $14.8 \pm 0.7$ \\
\hline
\end{tabular}


Appendix B. Formulas for calculating the amounts of sodium nitrite and sodium chloride to add to reach target concentrations in the water.

$\underline{\text { Molecular weights }}$

Sodium $\left(\mathrm{Na}^{+}\right)=22.99$

Nitrogen $(\mathrm{N})=14.01$

Oxygen $(\mathrm{O})=16.00$

Chloride $\left(\mathrm{Cl}^{-}\right)=35.45$

Nitrite $\left(\mathrm{NO}_{2}^{-}\right)=46.01$

Sodium Nitrite $\left(\mathrm{NaNO}_{2}\right)=69.00$

Sodium Chloride $(\mathrm{NaCl})=58.44$ $\underline{\text { Percentages }}$

$$
\begin{aligned}
& \mathrm{NO}_{2}{ }^{-}=66.7 \% \text { of } \mathrm{NaNO}_{2} \\
& (46.01 / 69.00=0.667 \times 100) \\
& \mathrm{Cl}-=60.7 \% \text { of } \mathrm{NaCl} \\
& (35.45 / 58.44=0.607 \times 100)
\end{aligned}
$$

\section{$\underline{\text { Calculations }}$}

Step 1. target concentration $x 45$ liters (L) of water $\{\mathbf{A}\}$

Step 2. divide $\{\mathrm{A}\}$ by 1000 to change milligrams $(\mathrm{mg})$ to grams $(\mathrm{g})\{\mathbf{B}\}$

Step 3. divide $\{\mathbf{B}\}$ by either 0.667 (for nitrite) or 0.607 (for chloride) to determine the amount of $\mathrm{NaNO}_{2}$ or $\mathrm{NaCl}$ to add to the water $\{\mathrm{C}\}$ 
Chapter 2: Physiological Responses of Arctic Char (Salvelinus alpinus) During a 5.5 Hour Transport with Ice-Slurry, AQUI-S ${ }^{\mathrm{TM}}$, and Carbon Dioxide 


\begin{abstract}
Physiological Responses of Arctic Char (Salvelinus alpinus) During a 5.5 Hour Transport with Ice-Slurry, AQUI-S ${ }^{\mathrm{TM}}$, and Carbon Dioxide
\end{abstract}

\author{
Christopher D. Nelson
}

Transporting fish is a fish culture process that produces physiological alterations in fish. Transport-related stimuli, such as netting, loading, unloading, and en route transport, are usually unavoidable and cause detectable physiological responses in food fish that can be deleterious to product quality and value. Minimizing such disturbances, therefore, may be beneficial in maintaining a high quality product. The objectives of this study were to determine the physiological responses of Arctic char to transport, and to determine if anesthesia $\left(\mathrm{CO}_{2}\right.$ or AQUI-S ${ }^{\mathrm{TM}}$ ) or ice exposure during transport could help minimize the anticipated physiological responses. Four transport treatments (water-only, $\mathrm{CO}_{2}$, AQUI-S ${ }^{\mathrm{TM}}$, and ice-slurry) were tested in triplicate. Insulated seafood totes, equipped with aerators and supplemental oxygen diffusers, served as the live-haul chambers. Each treatment tote was stocked with 50 Arctic char (mean 1.2 $\mathrm{kg}$ per fish) at the start of the study $(0 \mathrm{~h})$, and fish were exposed to transport treatments for $5.5 \mathrm{~h}$. Physiological responses (hematocrit, plasma cortisol, glucose, lactate and chloride) to the treatments were determined from blood samples taken from fish. Sampled fish were removed from the transport totes at 1.0, 2.5, 4.0, and $5.5 \mathrm{~h}$ during transport. Results indicate that the transport of char under the anesthetics tested did not alleviate transport-related physiological disturbances. Physiological responses were detected among all treatments during the $5.5 \mathrm{~h}$ study. Results also show that AQUI-S ${ }^{\mathrm{TM}}$ had no clear advantage over the water-only treatment, $\mathrm{CO}_{2}$ resulted in a more severe stress response (higher hematocrit and cortisol) compared to the wateronly treatment, and the ice-slurry treatment also resulted in a more severe stress response (higher cortisol, glucose and lactate) when compared to the water-only treatment. Overall, use of anesthetics during transport of food fish provided no clear advantage, and in the case of iceslurry and $\mathrm{CO}_{2}$, may have resulted in additional loss of product quality because of a more severe stress response. 


\section{List of Tables}

Table 1. Plasma glucose values (mean $\pm \mathrm{SEM}$ ) from arctic char (Salvelinus alpinus) for each transport treatment and sampling time. Same lower case letter indicates no significant difference between control and other treatments. Values recorded in $\mathrm{mg} / \mathrm{dL}$.

Table 2. Plasma chloride values (mean $\pm \mathrm{SEM}$ ) from arctic char (Salvelinus alpinus) for each transport treatment and sampling time. Same lower case letter indicates no significant difference between control and other treatments. Values recorded in $\mathrm{mEq} / \mathrm{L}$. 


\section{List of Figures}

Figure 1. Percent hematocrit (mean $\pm \mathrm{SEM}$ ) in arctic char exposed for $5.5 \mathrm{~h}$ to four transport treatments.

Figure 2. Plasma cortisol (mean $\pm \mathrm{SEM}$ ) in arctic char exposed for $5.5 \mathrm{~h}$ to four transport treatments.

Figure 3. Plasma lactate (mean $\pm \mathrm{SEM}$ ) in arctic char exposed for $5.5 \mathrm{~h}$ to four transport treatments. 


\section{Introduction}

Ensuring consistent and optimal product quality is a constant challenge to fish producers and processors. Under ideal conditions, fresh fish products such as rainbow trout fillets have a relatively short shelf life (Rasmussen 2001). Short shelf life relative to other meat products results partly from increased amounts of unsaturated fatty acids, which are more susceptible to oxidation (Haard 1992). Oxidation of fatty acids can lead to off-flavor and faster development of rancid fillets (Haard 1992). In addition, the weak collagen structure of fish muscle makes it very sensitive to muscle pH fluctuations, especially during harvest (Robb 2001; Rasmussen 2001). Struggle of fish during harvest and transport has been shown to result in rapid decreases in muscle $\mathrm{pH}$ post-mortem, affecting fillet quality through loss of fillet firmness and increased fillet gaping (Berg et al. 1997; Robb 2001).

Physical disturbances during harvest and transport of fish are routine in aquaculture and are unavoidable. Studies have shown that transport-related disturbances, such as netting, capture, loading and unloading, and en route transport, cause detectable physiological stress responses in fish (Robertson et al. 1988; Erikson et al. 1997; Barton 2000a). Poor water quality and high fish densities during transport also can serve as additional stressors (Robertson et al. 1988; Erikson et al. 1997). Although such disturbances are usually unavoidable, there may be ways to minimize the disturbances so that physiological responses in the fish are minimized and subsequent product quality may be maximized.

Anesthetics have been used widely during the transport of fish and may help alleviate physiological stress (Morales et al. 1990; Harrell 1992; Sandodden et al. 2001). Wedemeyer (1992) reported that using anesthetics during transport of fish could be helpful in reducing physical activity and overall metabolic rates, thereby leading to reduced physiological stress. 
Anesthetics that have been used in transporting fish include tricaine methanesulfanate (MS-222), benzocaine, etomidate, metomidate, clove oil and carbon dioxide (Amend et al. 1982; Gilderhus and Marking 1987; Mattson and Riple 1989; Gilderhus et al. 1991; Sandodden et al. 2001). Currently, carbon dioxide $\left(\mathrm{CO}_{2}\right)$ is the only anesthetic approved for use on U.S. food fish without a withdrawal period. However, use of $\mathrm{CO}_{2}$ on food fish during transport or harvest has several disadvantages. Fish exposed to elevated $\mathrm{CO}_{2}$ show increased aversive activity and reduced blood $\mathrm{pH}$, both of which may be deleterious to product quality (Robb 2001). AQUI-S ${ }^{\mathrm{TM}}$ (AQUIS Ltd., New Zealand), a proprietary form of clove oil, is an alternative anesthetic that has not yet been approved but is currently under review by the US Food and Drug Administration. Physiological and product quality studies on fish exposed to AQUI-S ${ }^{\mathrm{TM}}$ are limited, so its potential is yet unknown. Other additives, such as ice-slurries (ice + water) also have been used to help minimize stress during transport by inducing hypothermia (Wedemeyer 1992), and it is currently the most widely used anesthetic for food fish in West Virginia (B. Kenney personal comm.). Despite the possible shortcomings of anesthetics, they may still prove useful if they can decrease the stress responses of fish in comparison to harvest or transport without anesthesia.

In 2000, research conducted by West Virginia University as part of the West Virginia Aquaculture Research and Development Project, revealed significant variation in fillet yield and quality on farms sampled throughout West Virginia and neighboring Appalachian states. It was noted that harvest practices among farms was highly variable, ranging from on-site slaughter via asphyxiation to live-haul to the processing plant (B. Kenney personal comm.). The objective of the present study was to evaluate the effectiveness of transport under anesthesia (AQUI-S ${ }^{\mathrm{TM}}$, iceslurry, or $\mathrm{CO}_{2}$ ) in reducing the physiological stress responses in Arctic char (Salvelinus alpinus) in comparison to transport without anesthesia (aerated water only). The present study was part 
of a broader research project that investigated physiological responses during transport of live char and the effects of transport conditions on fillet quality. We hypothesized that fish transported under anesthesia would have reduced stress responses (hematocrit, plasma cortisol, chloride, glucose and lactate) compared to fish transported in water.

\section{Materials and Methods}

\section{$\underline{\text { Fish Care and Maintenance }}$}

Arctic char were raised at the Conservation Fund's Freshwater Institute, Shepherdstown, WV. Fish were housed in 1200-L fiberglass tanks supplied with oxygen-injected spring water (temperature $13.3 \pm 0.2^{\circ} \mathrm{C}$; dissolved oxygen $13.1 \pm 0.2 \mathrm{mg} / \mathrm{L} ; \mathrm{pH} 7.6 \pm 0.1$; total alkalinity $247.4 \pm 4.3 \mathrm{mg} / \mathrm{L}$; calcium hardness $236.4 \pm 2.1 \mathrm{mg} / \mathrm{L}$ and $11.7 \pm 0.7 \mathrm{mg} / \mathrm{L}$ free $\mathrm{CO}_{2}$ ). Photoperiod was maintained on a $14 \mathrm{~h} \mathrm{~L}: 10 \mathrm{~h} \mathrm{D}$ cycle. Fish were fed daily with commercial trout feed (Melick Aquafeed, Catawissa, PA). Throughout the study the mean fish weight was $1228.2 \pm 10.4 \mathrm{~g}$. All fish were fasted for two days prior to experimention.

\section{Experimental Design}

Four transport treatments (water, $\mathrm{AQUI}-\mathrm{S}^{\mathrm{TM}}, \mathrm{CO}_{2}$ anesthesia, and ice-slurry) were tested in triplicate. During each simulated transport, the four transport treatments were randomly assigned among four cubical live-haul chambers. Each treatment was included during each of the three transport trips, for a total of three replicates per treatment. Four insulated seafood totes (1000-L capacity), equipped with aerators and supplemental oxygen diffusers, served as the livehaul chambers during the study. Totes were secured onto a trailer and filled with spring water (approximately $800 \mathrm{~L}$ ). The anesthetics (AQUI-S ${ }^{\mathrm{TM}}, \mathrm{CO}_{2}$, and ice) were added immediately 
before the fish were stocked. For AQUI-S ${ }^{\mathrm{TM}}, 1 \mathrm{ml}$ of concentrated AQUI-S ${ }^{\mathrm{TM}}$ was added below the surface of the treatment tote and thoroughly mixed. The $\mathrm{CO}_{2}$ treatment was prepared and maintained using a micro pore diffuser (MBD 75 s A grade, Point Four Systems Inc., Port Moody, British Columbia, Canada) and a gas flow meter (Key Instruments, Trevose, PA). The $\mathrm{CO}_{2}$ system was connected by polyethylene tubing to a remote liquid $\mathrm{CO}_{2}$ cylinder (Messler MG Industries, Malvern, $\mathrm{PA}$ ). The $\mathrm{CO}_{2}$ treatment was checked via the $\mathrm{CO}_{2}$ nomogram method (APHA 1998) and had a mean of $55.0 \mathrm{mg} / \mathrm{L}$ free $\mathrm{CO}_{2}$. The ice-slurry treatment contained approximately 3 parts ice to 1 part water.

Five pre-transport control fish were sampled directly from the holding tanks as described below, before the start of each replicate experiment. Then, at the beginning of each transport $(0$ h), Arctic char were randomly netted from the holding tanks and 50 fish were placed into each replicate tote. Each simulated transport lasted 5.5 h, during which 5 fish were sampled from each tote at $1,2.5,4$, and $5.5 \mathrm{~h}$ for blood analyses.

Sampled fish were individually dip-netted, given a quick blow to the head, and blood was collected into lithium-heparinized syringes from vessels in the caudal peduncle (Houston 1990). Sampling was completed within 5 minutes of initial disturbance and each fish was sampled only once. Blood was transferred into heparinized microhematocrit tubes (in duplicate) and 3-ml lithium-heparinized tubes. Microhematocrit samples were centrifuged for $5 \mathrm{~min}$ at 11,500 rpm, and the percent hematocrit was determined using a microhematocrit reader (IEC, Needham Heights, MA). Blood collected into the 3-ml tubes was centrifuged for $10 \mathrm{~min}$ at $3500 \mathrm{rpm}$, and the resulting plasma transferred into $1.5-\mathrm{ml}$ microcentrifuge tubes. Plasma samples were stored at $-20^{\circ} \mathrm{C}$ until analyzed for cortisol, glucose, lactate and chloride. All plasma parameters were analyzed in duplicate. 
Plasma cortisol was analyzed by radioimmunoassay (RIA) using a commercially available kit (Coat-a-Count, Diagnostic Product Corp., Los Angeles, CA) and an automatic gamma counter (1470 Wizard Automatic Gamma Counter, Wallac Oy., Finland). The performance characteristics of the cortisol RIA were as followes: a 91.7\% standard recovery; within-assay variability, defined as the coefficient of variation (CV), 4.3\%; between-assay variability, defined as the $\mathrm{CV}, 4.1 \%$; the minimum level of sensitivity was $2.0 \mathrm{ng}$ and samples below the minimum level of sensitivity were assigned a value of zero (Barton et al. 1980). Plasma glucose and lactate were analyzed by an automatic glucose/lactate analyzer (YSI 2300 Select, Yellow Springs, $\mathrm{OH}$ ), and plasma chloride was determined by a digital chloridometer (Labconco Co., Lenexa, KS).

During each replicated transport, temperature, dissolved oxygen, $\mathrm{pH}$, and total ammonianitrogen (TAN) were measured. Temperature and dissolved oxygen were measured with a handheld meter (YSI Model 58 or 95, Yellow Springs, $\mathrm{OH}$ ). The water $\mathrm{pH}$ also was measured with a hand-held meter (YSI Model 60/10 FT, Yellow Springs, OH). Total ammonia-nitrogen was determined using a commercially available test kit (Hach, Co., Loveland, CO). Water quality parameters from each treatment are included in Appendix A.

\section{$\underline{\text { Statistical Analyses }}$}

A repeated measure plus control (initial values) design was used in the present study. Data were analyzed with treatments (water, AQUI-S, ice-slurry and $\left.\mathrm{CO}_{2}\right)$ and sampling times (1, $2.5,4$, and $5.5 \mathrm{~h})$ as factors. When significant $(\mathrm{p}<0.05)$, means were further separated using Fisher's Least Squared Difference. Results are presented as treatment means \pm standard error of the mean (SEM). All data were analyzed using Microsoft Excel (Excel XP, Microsoft Co., Redmond, CA) and SAS (SAS 8.2, SAS Inst., Cary, NC). 


\section{Results}

Physiological stress responses (hematocrit, plasma cortisol, glucose, lactate and chloride) showed significant time and treatment effects among transport treatments. Percent hematocrit increased in all treatments within the first hour of transport (Fig. 1). Water, AQUI-S ${ }^{\mathrm{TM}}$, and iceslurry treatments recovered to near resting levels by $5.5 \mathrm{~h}$; however, no recovery was observed for the $\mathrm{CO}_{2}$ transport treatment. Mean hematocrit of fish from the $\mathrm{CO}_{2}$ treatment was significantly different from all other transport treatments through the end of the study (5.5 h).

Plasma cortisol increased in all treatments within the first hour of transport (Fig. 2). The water and $\mathrm{CO}_{2}$ treatments were significantly higher than the control (pre-transport group) at $0 \mathrm{~h}$. By $2.5 \mathrm{~h}$, all transport treatments were significantly higher than the control. All treatments (with the exception of AQUI-S at $5.5 \mathrm{~h}$ ) remained significantly higher than the control throughout the $5.5 \mathrm{~h}$ transport (Fig. 2). Overall plasma cortisol concentrations were significantly different between AQUI-S ${ }^{\mathrm{TM}}$ and ice-slurry, between AQUI-S ${ }^{\mathrm{TM}}$ and $\mathrm{CO}_{2}$ and between water and $\mathrm{CO}_{2}$ treatments $(\mathrm{p}=0.04,0.01$, and 0.03 , respectively).

Plasma glucose showed treatment-dependent responses. The water treatment showed a trend of increasing plasma glucose with time, with the mean glucose concentration at $5.5 \mathrm{~h}$ significantly higher than $0,1.0$, or $2.5 \mathrm{~h}$ (Table 1 ). Glucose was significantly increased in the ice-slurry treatment at $1 \mathrm{~h}$ compared to $0 \mathrm{~h}$, and remained elevated through the end of the study (5.5 h). No clear glucose trends were detected in the AQUI-S ${ }^{\mathrm{TM}}$ or $\mathrm{CO}_{2}$ treatments (Table 1). Overall plasma glucose concentrations were significantly different between AQUI-S ${ }^{\mathrm{TM}}$ and iceslurry, between $\mathrm{CO}_{2}$ and ice-slurry, and between $\mathrm{CO}_{2}$ and water treatments $(\mathrm{p}=0.03,0.01$, and 0.04 , respectively). 
Plasma lactate levels increased in all treatments by the first hour of transport (Fig. 3). Water, $\mathrm{AQUI}-\mathrm{S}^{\mathrm{TM}}$, and $\mathrm{CO}_{2}$ treatments all recovered to near-resting levels by $5.5 \mathrm{~h}$ of transport; however, no recovery was observed for the ice-slurry treatment group which remained elevated through the end of the $5.5 \mathrm{~h}$ transport. Significant plasma chloride differences were detected among treatments, with mean plasma chloride of ice-treated fish being significantly higher than all other treatment groups (Table 2).

\section{Discussion}

Use of anesthetics during transport of non-food fish has been well documented (Strange and Schreck 1978; Robertson et al. 1988; Urbinati and Carreiro 2001; Sandodden et al. 2001), and adoption and adaptation of the use of anesthetics to the food fish industry may help minimize physiological stress and therefore, increase product quality. In the present study, we hypothesized that arctic char transported under various types of anesthesia would have reduced physiological stress responses (hematocrit, plasma cortisol, glucose, lactate, and chloride) compared to fish transported in water alone; however, the results did not support our hypothesis. Instead, the results suggest that different anesthetics used during the $5.5 \mathrm{~h}$ simulated transport were not effective in consistently reducing the stress responses of transported fish compared to fish transported in water alone.

Hematocrit is a useful indicator of stress in fish (Barton and Iwama 1991). Increases in percent hematocrit are common during stress responses, and functions to increase the oxygen carrying capacity of the blood in preparation for a fight or flight response (Soivio et al. 1980). Hematocrit usually returns to pre-stress levels within a few hours after the demand for oxygen returns to resting levels (Wendelaar Bonga 1997). In the present study, percent hematocrit was 
$30.6 \%$ before transport and increased among treatments to between 37.0 and $49.5 \%$ during transport, indicating that use of anesthesia during transport did not prevent or minimize the stress response. All treatments, with the exception of the $\mathrm{CO}_{2}$ treatment, returned to near resting levels by $5.5 \mathrm{~h}$ indicating fish in these treatments were acclimating to the transport conditions.

Mean hematocrit of fish from the $\mathrm{CO}_{2}$ treatment remained significantly higher than all other treatments at 4.0 and $5.5 \mathrm{~h}$. Higher hematocrit in the $\mathrm{CO}_{2}$ treatment may reflect a transient Bohr effect on the red blood cells of $\mathrm{CO}_{2}$ anesthetized fish (Eddy 1977). A $\mathrm{CO}_{2}$-induced Bohr effect has been shown to reduce the affinity of the red blood cells for oxygen (Eddy 1977), thereby necessitating the need for more red blood cells in circulation to meet the organism's oxygen demands. Thus, because $\mathrm{CO}_{2}$ anesthetized fish showed a prolonged and elevated stress (hematocrit) response, use of $\mathrm{CO}_{2}$ anesthesia may not be ideal for transport of fish compared to other potential transport treatments. While hematocrit is a useful physiological parameter to measure as an indicator of stress, other parameters such as plasma cortisol, glucose, lactate, and chloride need to be considered since they are indicative of different physiological systems of the fish and may relate to changes in end-product quality through other mechanisms.

Plasma cortisol is a primary stress response of fish, meaning its hormonal action directs other (secondary) physiological changes during a stress response (Strange and Schreck 1978; Barton et al.1980; Wendelaar Bonga 1997). Increases in plasma cortisol during transport of fish are routinely observed (Carmichael et al. 1984; Robertson et al. 1988; Urbinati and Carreiro 2001). In all transport treatments of the present study, plasma cortisol of fish in totes at $0 \mathrm{~h}$ was higher $(\mathrm{p}<0.05)$ compared to pre-transport control fish, indicating that netting and moving fish into the transport totes had already initiated a stress response before the fish were even transported (Strange and Schreck 1978; Barton et al.1980). 
Mean cortisol from all transport treatments continued to increase through $2.5 \mathrm{~h}$ transport, with the exception of the water-only treatment. The AQUI-S ${ }^{\mathrm{TM}}$ and water treatments showed a decreasing or stabilizing trend towards resting or pre-transport levels by $5.5 \mathrm{~h}$ transport; fish in these treatments may have been recovering during transport to their resting pre-transport levels. Similar to hematocrit responses discussed above, transport with $\mathrm{CO}_{2}$ anesthesia resulted in the highest cortisol responses of all treatments through $2.5 \mathrm{~h}$ transport, indicating use of $\mathrm{CO}_{2}$ is not ideal for reducing the stress responses of fish during transport. Instead, use of $\mathrm{CO}_{2}$ during transport may actually prolong or exacerbate the stress response in fish.

Although $\mathrm{CO}_{2}$ resulted in significantly elevated cortisol responses through $2.5 \mathrm{~h}$, the iceslurry treatment exhibited the highest level of all treatments at $5.5 \mathrm{~h}$ transport. This response may be the result of a slower cortisol response resulting from the hypothermic transport conditions. Similar results were reported by Barton and Peter (1982) who detected significantly increased plasma cortisol responses in fingerling rainbow trout at $4 \mathrm{~h}$ immersion in chilled $\left(1^{\circ} \mathrm{C}\right)$ water. Thus, ice-slurry may not be ideal for transport of char for longer than $2-3 \mathrm{~h}$, but may yet be useful for shorter transport times.

Blood metabolites, such as glucose and lactate, are characterized as secondary stress responses in fish and levels generally increased during and immediately following exposure to handling and transport (Morgan and Iwama 1997; Wendelaar Bonga 1997). Following a stressor, increases in plasma glucose are often observed in order to meet the elevated energy demand of the body (Morgan and Iwama 1997). Increased plasma lactate levels, however, reflect anaerobic metabolism due to increased activity or decreases in oxygen availability (Thomas et al. 1999) and can indicate a failure of homeostasis (Wardle 1978). In the present study, char plasma glucose showed a distinct treatment-dependent response with no single 
treatment indicating an overall advantage when compared to the water-only treatment. In particular, glucose concentrations in the ice-slurry treatment were higher than all of the other treatments (with the exception of the water treatment at $5.5 \mathrm{~h}$ ), indicating this treatment may be more deleterious to end-product quality than transport with water-only.

Plasma lactate responses also showed a significant increase among all treatments from $<$ $4 \mathrm{mg} / \mathrm{dL}$ at $0 \mathrm{~h}$ to $>65 \mathrm{mg} / \mathrm{dL}$ at $1.0 \mathrm{~h}$. All treatments responded with a gradual recovery to $0 \mathrm{~h}$ levels except for the ice-slurry treatment, which remained elevated throughout the $5.5 \mathrm{~h}$ transport, again indicating anesthesia did not provide any advantage over the water-only treatment in minimizing the stress response associated with transport of char.

Disturbance to osmoregulatory steady states are also characteristic of secondary stress responses in fish (Wedemeyer 1972; Mazeaud et al. 1977; Carmichael et al. 1984), and include disturbance such as handling and transport (Carmichael et al. 1984; Mazik et al. 1991). In the present study, a significant difference in plasma chloride was indicated, but all plasma values for all treatments were within normal ranges reported for fish (Barton 2000b). Thus, plasma chloride responses did not indicate any anesthetic treatment advantages during transport compared to the water-only treatment.

\section{Conclusion}

The anesthetic treatments investigated in the present study (AQUI-S $\mathrm{S}^{\mathrm{TM}}$, ice-slurry, and $\mathrm{CO}_{2}$ ) were not effective in consistently reducing the stress responses of Arctic char during the $5.5 \mathrm{~h}$ simulated transport. All treatment groups showed stress responses for each of the parameters measured. Use of AQUI-S during a $5.5 \mathrm{~h}$ transport indicated no clear advantage over water-only treatment and thus its use cannot be justified. Ice-slurry treatment actually indicated 
more severe stress responses compared to the water-only treatment, as indicated by significantly higher cortisol, glucose, and lactate responses. Because stress responses immediately before and during harvest have been shown to affect product quality (Robb 2001), one can assume anything that increases the stress response before harvest will likely have a similar increased negative effect on the end product quality and therefore should be avoided if possible. Similar to results for the ice-slurry treatment, use of $\mathrm{CO}_{2}$ resulted in more severe stress responses (hematocrit and cortisol) compared to the water-only control and likely indicates a deleterious rather then beneficial affect on end product quality. Overall, use of anesthetics during transport of food fish provided no clear advantage, and in the case of ice-slurry and $\mathrm{CO}_{2}$, may have resulted in additional loss of product quality because of a more severe stress response. 


\section{References}

Amend, F. A., B. A. Goven, and D. G. Elliot. 1982. Etomidate: effective dosages for a new fish anesthetic. Transactions of the American Fisheries Society 111:337-341.

APHA (American Public Health Association), American Public Water Works Association, and Water Pollution Control Federation. 1998. Standard methods for the examination of water and wastewater. $20^{\text {th }}$ edition. Washington, D. C., USA.

Barton, B. A. 2000a. Salmonid fishes differ in their cortisol and glucose responses to handling and transport stress. North American Journal of Aquaculture 62:12-18.

Barton, B. A. 2000b. Stress. Pages 892-898 in R. R. Stickney, editor. Encyclopedia of Aquaculture. John Wiley \& Sons, Inc., New York, New York.

Barton, B. A., and G. K. Iwama. 1991. Physiological changes in fish from stress in aquaculture with emphasis on the response and effects on corticosteroids. Annual Review of Fish Diseases 1:3-26.

Barton, B. A., and R. E. Peter. 1982. Plasma cortisol stress responses in fingerling rainbow trout, Salmo gairdneri Richardson, to various transport conditions, anaesthesia, and cold shock. Journal of Fish Biology 20:39-51.

Barton, B. A., R. E. Peter, and C. R. Paulencu. 1980. Plasma cortisol levels of fingerling rainbow trout (Salmo gairdneri) at rest, and subjected to handling, confinement, transport, and stocking. Canadian Journal of Fisheries and Aquatic Sciences 37:805-811.

Berg, T., U. Erikson, and T. S. Nordtvedt. 1997. Rigor mortis assessment of Atlantic salmon (Salmo salar) and effects and stress. Journal of Food Science 62:439-446.

Carmichael, G. J., J. R. Tomasso, B. A. Simco, and K. B. Davis. 1984. Characterization 
and alleviation of stress associated with hauling largemouth bass. Transactions of the American Fisheries Society 113:778-785.

Eddy, F. B., J. P. Lomholt, R. E. Weber, and K. Johansen. 1977. Blood respiratory properties of rainbow trout (Salmo gairdneri) kept in water of high $\mathrm{CO}_{2}$ tension. Journal of Experimental Biology 67:37-47.

Erikson, U., T. Sigholt, and A. Seland. 1997. Handling stress and water quality during live transportation and slaughter of Atlantic salmon (Salmo salar). Aquaculture 149:243252.

Gilderhus, P. A., and L. L. Marking. 1987. Comparative efficacy of 16 anaesthetic chemicals on rainbow trout. North American Journal of Fisheries Management 7:288292.

Gilderhus, P. A., C. A. Lemm, and L. C. Woods III. 1991. Benzocaine as an anesthetic for striped bass. The Progressive Fish-Culturist 53:105-107.

Haard, N. F. 1992. Technological aspects of extending prime quality of seafood: A review. 1992. Journal of Aquatic Food Product Technology 1:9-27.

Harrell, R. M. 1992. Stress mitigation by use of salt and anesthetic for wild striped bass captured for brood stock. Progressive Fish-Culturist 54:228-233.

Houston, A. H. 1990. Blood and circulation. Pages 273-334 in C. B. Schreck and P. B. Moyle, editors. Methods for fish biology. American Fisheries Society, Bethesda, Maryland.

Mattson, N. S., and T. H. Ripple. 1989. Metomidate, a better anaesthetic for cod (Gadhus morhua) in comparison with benzocaine, MS-222, Chlorbutanol, and Phenoxyethanol. Aquaculture 83:89-94. 
Mazeaud, M. M., F. Mazeaud, and E. H. Donaldson. 1977. Stress resulting from handling in fish: primary and secondary effects. Transactions of the American Fisheries Society 106:201-212.

Mazik, P. M., B. A. Simco, and N. C. Parker. 1991. Influence of water hardness and salts on survival and physiological characteristics of striped bass during transport. Transactions of the American Fisheries Society 120:121-126.

Morales, A. E., L. Garcia-Rejon, and M. De La Higuera. 1990. Influence of handling and/or anaesthesia on stress response in rainbow trout. Effects on liver primary metabolism. Comparative Biochemistry and Physiology 95A:87-93.

Morgan, J. D. and G. K. Iwama. 1997. Measurements of stressed states in the field. Pages 247-270 in G. W. Iwama, A. D. Pickering, J. P. Sumpter, and C. B. Sckreck, editors. Fish stress and health in aquaculture. Cambridge University Press.

Rasmussen, R. S. 2001. Quality of farmed salmonids with emphasis on proximate composition, yield and sensory characteristics. Aquaculture Research 32:767-786.

Robb, D. H. F. 2001. The relationship between killing methods and quality. Pages 220233 in S. C. Kestin and P. D. Warriss, editors. Farmed Fish Quality. Blackwell Science, Ltd, Malden, MA.

Robertson, L., Thomas, P., and Arnold, C. R. 1988. Plasma cortisol and secondary stress responses of cultured red drum (Sciaenops ocellatus) to several transportation procedures. Aquaculture 68:115-130.

Sandodden, R., B. Finstad, and M. Iversen. 2001. Transport stress in Atlantic salmon (Salmo salar L.): anaesthesia and recovery. Aquaculture Research 32:87-90.

Soivio, A., K. Nikinmaa, and K. Westman. 1980. The blood oxygen binding 
properties of hypoxic Salmo gairdneri. Journal of Comparative Physiology 136:83-87.

Strange, R. J., and C. B. Schreck. 1978. Anaesthetic and handling stress on survival and cortisol concentration in yearling chinook salmon (Oncorhynchus tshawytscha). Journal of the Fisheries Board of Canada 35:345-349.

Thomas, P. M., N. W. Pankhurst, and H. A. Bremner. 1999. The effect of stress and exercise on post-mortem biochemistry of Atlantic salmon and rainbow trout. Journal of Fish Biology 54:1177-1196.

Urbinati, E. C., and P. C. Falanghe Carreiro. 2001. Metabolic and hormonal responses of Matrinxa, Brycon cephalus, (teleost: Characidae) to transport stress under influence of benzocaine. Journal of Aquaculture in the Tropics 16:75-85.

Wardle, C. S. 1978. Non-release of lactic acid from anaerobic swimming muscle of plaice Pleuronectes platessa L: a stress reaction. Journal of Experimental Biology $77: 141-155$.

Wedemeyer, G. A. 1972. Some physiological consequences of hauling stress in juvenile coho salmon (Oncorhynchus kisutch) and steelhead trout (Salmo gairdneri). Journal of the Fisheries Research Board of Canada 29:1780-1783.

Wedemeyer, G. A. 1992. Transporting and handling smolts. Smolt Qulaity Symposium. World Aquaculture 23:47-50.

Wendelaar Bonga, S. E. 1997. The stress response in fish. Physiological Reviews 77(3):591623. 
Table 1. Mean \pm SEM values for plasma glucose from arctic char (Salvelinus alpinus) for each transport treatment and sampling time. Same lower case letter indicates no significant difference between control and other treatments. Values recorded in $\mathrm{mg} / \mathrm{dL}$.

\begin{tabular}{ccccc}
\hline Time $(\mathrm{hr})$ & Water & AQUI-S & Ice-slurry & Carbon dioxide \\
\hline 0 & $79.5 \pm 0.6 \mathrm{a}$ & $79.5 \pm 0.6 \mathrm{a}$ & $79.5 \pm 0.6 \mathrm{a}$ & $79.5 \pm 0.6 \mathrm{ab}$ \\
1.0 & $78.1 \pm 3.6 \mathrm{a}$ & $85.3 \pm 5.1 \mathrm{ab}$ & $97.5 \pm 3.1 \mathrm{~b}$ & $77.2 \pm 1.0 \mathrm{a}$ \\
2.5 & $84.5 \pm 6.0 \mathrm{a}$ & $87.3 \pm 5.2 \mathrm{ab}$ & $95.3 \pm 4.0 \mathrm{~b}$ & $77.8 \pm 6.7 \mathrm{a}$ \\
4.0 & $91.9 \pm 7.3 \mathrm{ab}$ & $92.1 \pm 3.0 \mathrm{~b}$ & $98.9 \pm 5.5 \mathrm{~b}$ & $81.4 \pm 2.5 \mathrm{ab}$ \\
5.5 & $102.5 \pm 4.5 \mathrm{~b}$ & $88.2 \pm 3.7 \mathrm{ab}$ & $97.4 \pm 6.2 \mathrm{~b}$ & $88.3 \pm 0.6 \mathrm{~b}$ \\
\hline
\end{tabular}


Table 2. Mean \pm SEM values for plasma chloride from arctic char (Salvelinus alpinus) for each transport treatment and sampling time. Same lower case letter indicates no significant difference between control and other treatments. Values recorded in $\mathrm{mEq} / \mathrm{L}$.

\begin{tabular}{ccrrr}
\hline Time $(\mathrm{hr})$ & Water & AQUI-S & Ice-slurry & Carbon dioxide \\
\hline 0 & $115.2 \pm 2.8 \mathrm{a}$ & $115.2 \pm 2.8 \mathrm{a}$ & $115.2 \pm 2.8 \mathrm{a}$ & $115.2 \pm 2.8 \mathrm{a}$ \\
1.0 & $116.2 \pm 4.3 \mathrm{a}$ & $113.6 \pm 2.0 \mathrm{a}$ & $123.7 \pm 3.6 \mathrm{ab}$ & $119.8 \pm 4.0 \mathrm{a}$ \\
2.5 & $118.2 \pm 3.7 \mathrm{a}$ & $114.4 \pm 3.4 \mathrm{a}$ & $126.1 \pm 1.4 \mathrm{~b}$ & $119.0 \pm 3.2 \mathrm{a}$ \\
4.0 & $117.6 \pm 2.9 \mathrm{a}$ & $120.0 \pm 2.5 \mathrm{a}$ & $121.1 \pm 0.5 \mathrm{ab}$ & $116.0 \pm 4.3 \mathrm{a}$ \\
5.5 & $115.4 \pm 2.9 \mathrm{a}$ & $117.6 \pm 0.5 \mathrm{a}$ & $117.0 \pm 4.1 \mathrm{a}$ & $113.7 \pm 3.7 \mathrm{a}$ \\
\hline
\end{tabular}


Figure 1. Percent hematocrit (mean $\pm \mathrm{SEM}$ ) in arctic char exposed for $5.5 \mathrm{~h}$ to four transport treatments

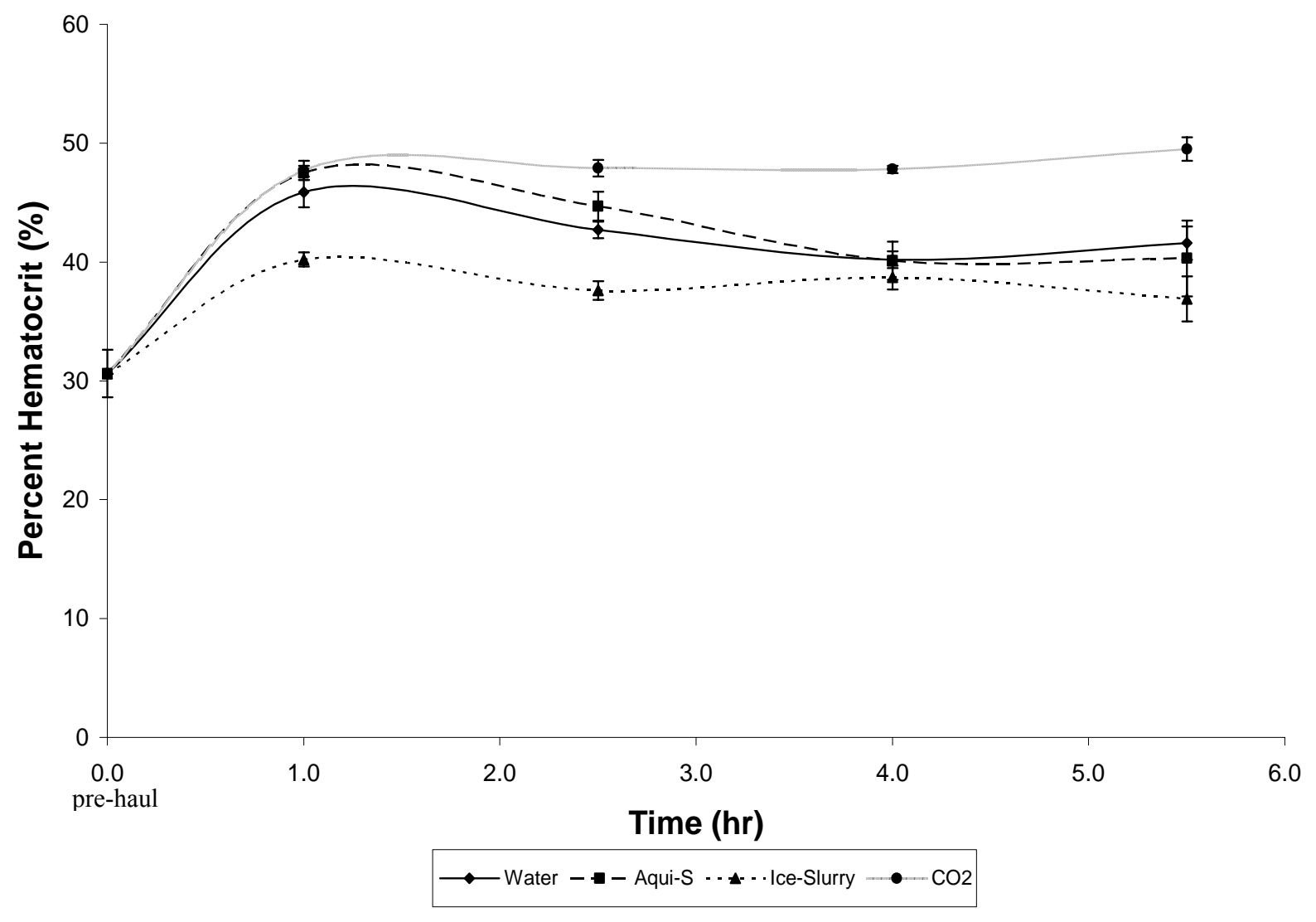


Figure 2. Plasma cortisol (mean $\pm \mathrm{SEM}$ ) in arctic char exposed for $5.5 \mathrm{~h}$ to four transport treatments

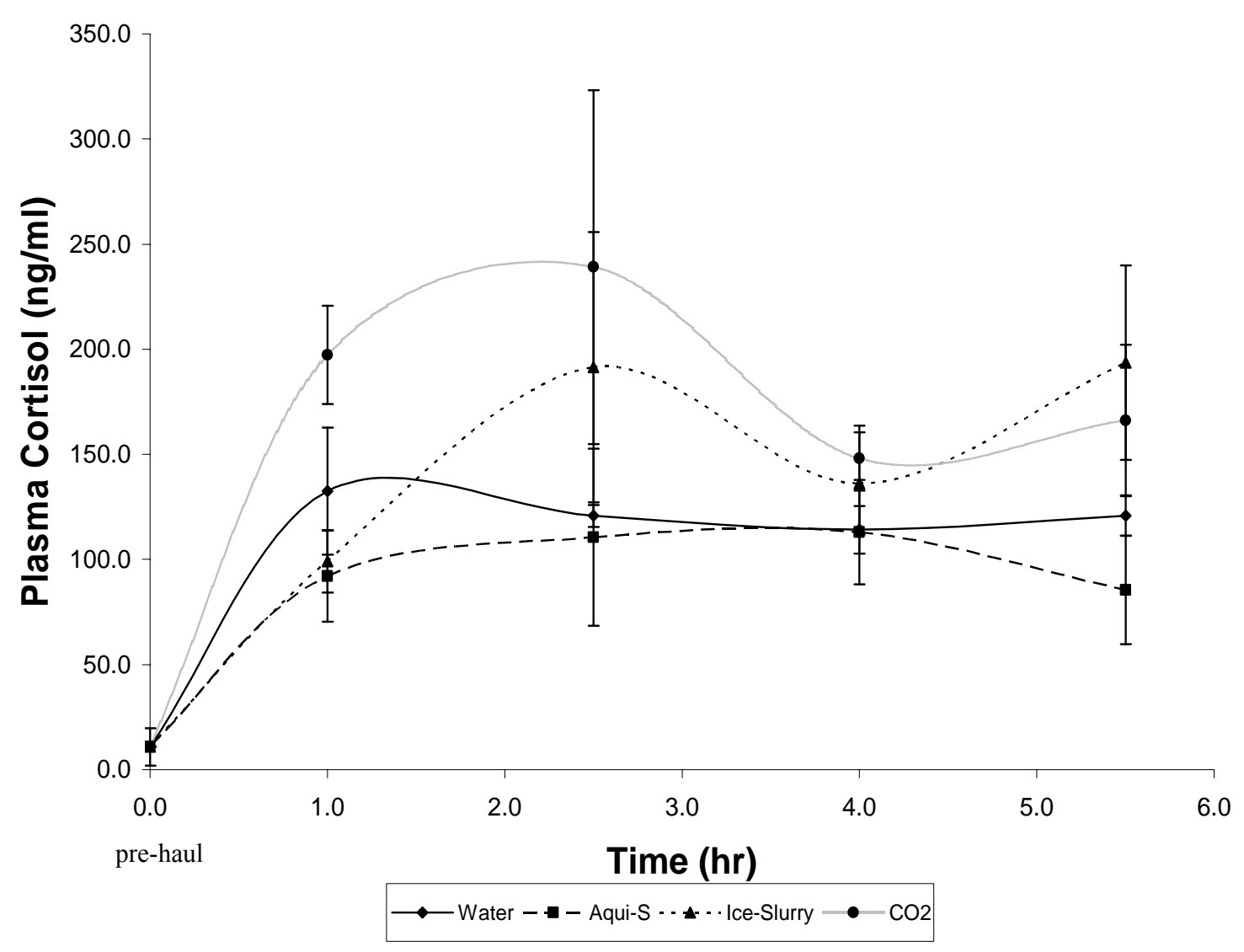


Figure 3. Plasma lactate (mean $\pm \mathrm{SEM}$ ) in arctic char exposed for $5.5 \mathrm{~h}$ to four transport treatments

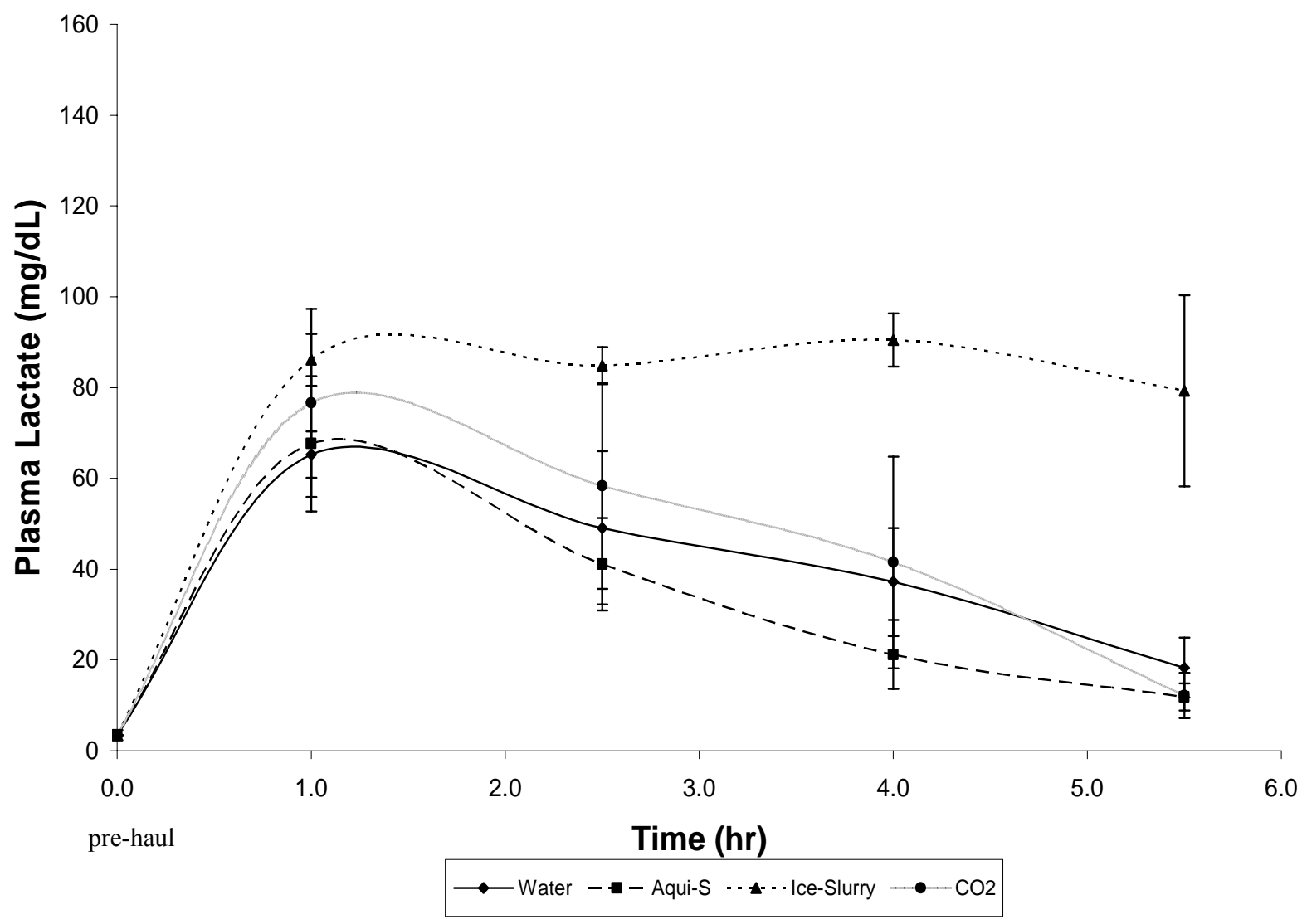


Appendix A. Mean \pm SEM of water quality values from each hour, with the exception of total ammonia-nitrogen (TAN) which was measured only at $5.5 \mathrm{~h}$, and treatment for the $5.5 \mathrm{~h}$ transport experiment.

\begin{tabular}{cccccc}
\hline $\begin{array}{c}\text { Transport } \\
\text { Treatment }\end{array}$ & Hour & $\begin{array}{c}\text { Temperature } \\
\left({ }^{\circ} \mathrm{C}\right)\end{array}$ & $\begin{array}{c}\text { Dissolved } \\
\text { Oxygen }(\mathrm{mg} / \mathrm{L})\end{array}$ & $\mathrm{pH}$ & TAN (mg/L) \\
\hline Water & 1 & $14.4 \pm 0.4$ & $10.4 \pm 0.4$ & $7.78 \pm 0.03$ & $\mathrm{NA}$ \\
Water & 2.5 & $13.9 \pm 0.8$ & $11.2 \pm 0.6$ & $7.89 \pm 0.06$ & $\mathrm{NA}$ \\
Water & 4 & $12.9 \pm 0.5$ & $11.1 \pm 0.7$ & $8.01 \pm 0.04$ & $\mathrm{NA}$ \\
Water & 5.5 & $13.0 \pm 0.4$ & $11.3 \pm 1.3$ & $8.05 \pm 0.05$ & $0.9 \pm 0.2$ \\
AQUI-S & 1 & $14.5 \pm 0.4$ & $10.3 \pm 0.5$ & $7.77 \pm 0.01$ & $\mathrm{NA}$ \\
AQUI-S & 2.5 & $14.2 \pm 0.5$ & $12.7 \pm 1.0$ & $7.91 \pm 0.02$ & $\mathrm{NA}$ \\
AQUI-S & 4 & $13.5 \pm 0.7$ & $11.9 \pm 1.2$ & $8.02 \pm 0.02$ & $\mathrm{NA}$ \\
AQUI-S & 5.5 & $13.6 \pm 0.7$ & $10.6 \pm 1.5$ & $8.01 \pm 0.04$ & $1.1 \pm 0.3$ \\
Ice-slurry & 1 & $0.3 \pm 0$ & $14.2 \pm 0.3$ & $7.79 \pm 0.02$ & $\mathrm{NA}$ \\
Ice-slurry & 2.5 & $0.3 \pm 0.2$ & $16.8 \pm 1.2$ & $7.83 \pm 0.06$ & $\mathrm{NA}$ \\
Ice-slurry & 4 & $0.3 \pm 0$ & $15.9 \pm 1.3$ & $8.02 \pm 0.03$ & $\mathrm{NA}$ \\
Ice-slurry & 5.5 & $0.3 \pm 0.2$ & $15.6 \pm 3.6$ & $8.04 \pm 0.04$ & $0.6 \pm 0.2$ \\
$\mathrm{CO}_{2}$ & 1 & $13.9 \pm 0.5$ & $10.5 \pm 0.8$ & $7.04 \pm 0.02$ & $\mathrm{NA}$ \\
$\mathrm{CO}_{2}$ & 2.5 & $13.9 \pm 0.6$ & $10.8 \pm 0.5$ & $7.04 \pm 0.05$ & $\mathrm{NA}$ \\
$\mathrm{CO}_{2}$ & 4 & $14.0 \pm 0.3$ & $10.5 \pm 0.7$ & $7.05 \pm 0.02$ & $\mathrm{NA}$ \\
$\mathrm{CO}_{2}$ & 5.5 & $14.8 \pm 0.05$ & $10.3 \pm 1.1$ & $7.00 \pm 0.06$ & $0.8 \pm 0.1$ \\
\hline
\end{tabular}




\section{Curriculum Vitae}

\section{Christopher D. Nelson}

Updated 06/14/03

Office Address:

West Virginia University

Division of Forestry

322 Percival Hall

Morgantown, WV 26506-6125

(304) 293-3794 ext. 2309

fax (304) 293-4826

\section{Educational Background}

M. S. West Virginia University (Aug. 2003)

Major: Fisheries Resources

B. S. $\quad$ University of Georgia (2000)

Major: Fisheries \& Aquaculture

A. S. $\quad$ Abraham Baldwin Agricultural College (1999)

Major: Forest Resources

\section{Research Experience}

Position: Graduate Research Assistant

Place: $\quad$ West Virgnia University, Morgantown, West Virginia

Duties: Conducted research for Master's Thesis: 1) examined the effects of the interaction of nitrite and carbon dioxide on the survival and physiological stress responses of rainbow trout; and 2) examined the effects of transport-related stressors on arctic char. Assisted other graduate students in field research (e.g, boat and backpack electrofishing, water quality sampling) and lab research (e.g., bleeding fish, analyzing blood and plasma samples).

Dates: $\quad$ August 2001 - August 2003

Supervisor: Patricia M. Mazik, Ph.D.

Position: $\quad$ Undergraduate Fisheries \& Aquaculture Student

Place: $\quad$ University of Georgia, Athens, Georgia

Duties: $\quad$ Examined the effects of hybrid striped bass on largemouth bass in a small wildlife management pond and investigated the amount of public usage in a wildlife management area.

Dates: $\quad$ August 2000 - December 2000

Supervisors: Robert Reinert, Ph.D. and James Shelton, Ph.D. 


\section{Relevant Skills and Courses}

Computer skills: Experience using Microsoft Word, Excel, and PowerPoint, ArcGIS, SAS, and MARK.

Presentation skills: Training in oral and written communications.

Courses: Biology, Inorganic and Organic Chemistry, Statistics, Biometrics, Quantitative Ecology, Forest Ecology, Vertebrate and Invertebrate Zoology, Soils and Hydrology, Fisheries Management, Fish Physiology, Fish Culture, Water Quality Management, Icthyology, Limnology, Fish and Wildlife Management, Aquatic Toxicology, Fish Ecology

\section{Certifications}

First Aid/CPR

Backpack Electrofishing

Defensive Driving

\section{Professional Organizations}

American Fisheries Society

Bass Anglers Sportsman Society

West Virginia Aquaculture Association

\section{References}

Patricia M. Mazik, Ph.D.

West Virginia University

Division of Forestry

322 Percival Hall

Morgantown, WV 26506-6125

(304) 293-3794 ext. 2431

fax (304) 293-4826

pmazik@wvu.edu

P. Brett Kenney, Ph.D.

West Virginia University

Division of Animal and Veterinary Sciences

1042 Agricultural Sciences Building

P. O. Box 6108

Morgantown, WV 26506-6108

(304) 293-2406 ext. 4423

fax (304) 293-2232

bkenney@wvu.edu
Stuart A.Welsh, Ph.D.

West Virginia University

Division of Forestry

322 Percival Hall

Morgantown, WV 26506-6125

(304) 293-3794

fax (304) 293-4826

swelsh@wvu.edu

Melody L. M. Danley, M.S.

West Virginia University

Division of Forestry

322 Percival Hall

Morgantown, WV 26506-6125

(304) 293-3794 ext. 2323

fax (304) 293-4826

mldanley@hotmail.com 